\title{
Enhancing the Efficacy of Microwave Blanching-cum-black Mould Inactivation of Whole Garlic (Allium sativum L.) Bulbs Using Ultrasound: Higher Inactivation of Peroxidase, Polyphenol Oxidase, and Aspergillus niger at Lower Processing Temperatures
}

\author{
Sudarshanna $\operatorname{Kar}^{1}$ • P. P. Sutar ${ }^{1}$ (D) \\ Received: 2 July 2021 / Accepted: 18 January 2022 / Published online: 4 February 2022 \\ (c) The Author(s), under exclusive licence to Springer Science+Business Media, LLC, part of Springer Nature 2022
}

\begin{abstract}
The freshly harvested whole garlic bulbs require the inactivation of peroxidase (POD), polyphenol oxidase (PPO), and Aspergillus niger. However, the conventional hot water blanching and modern pretreatment like ultrasound (US) and microwave (MW) cannot individually inactivate both the enzymes and Aspergillus niger to the desired levels without compromising the quality of the garlic due to either of the higher process temperatures $\left(>85^{\circ} \mathrm{C}\right)$ or prolonged treatment times. Therefore, a two-stage sequential US followed by MW pretreatment for garlic bulbs was developed for simultaneous inactivation of POD, PPO, and Aspergillus niger to the desired levels and overcome the individual pretreatment drawbacks. The separate experiments were conducted for US and MW pretreatment using central composite design, and optimization was carried out using response surface methodology. When temperature constraint was considered during optimization, the US was able to reduce POD, PPO, and Aspergillus niger by $80.87 \%, 93.80 \%$, and $2.60 \mathrm{logs}$, respectively, whereas MW reduced POD, PPO, and Aspergillus niger by $77.84 \%, 77.04 \%$, and 1.90 logs, respectively. The US treatment $\left(58.43 \mathrm{WL}^{-1}\right.$ ultrasound power density for 40 min with an initial bath temperature of $\left.60{ }^{\circ} \mathrm{C}\right)$ followed by $\mathrm{MW}$ treatment $\left(3 \mathrm{Wg}^{-1} \mathrm{MW}\right.$ power density for 120 s) resulted in $90.37 \%$ POD and $92.38 \%$ PPO inactivation with 2.62 log reduction in Aspergillus niger. The maximum temperature reached in US $+\mathrm{MW}$ process was $83{ }^{\circ} \mathrm{C}$ which ensured no severe thermal damage to the garlic bulbs. The scanning electron microscopic images indicated that ultrasonication induced the porous structure in garlic and helped microwaves increase the product temperature rapidly and achieve the higher inactivation of enzymes and Aspergillus niger. Thus, the US was found to be enhancing the efficacy of the MW heating process.
\end{abstract}

Keywords Pretreatment · Ultrasound Microwave $\cdot$ Inactivation $\cdot$ Enzyme $\cdot$ Aspergillus niger

\section{Introduction}

Due to the pandemic taking over the world, the demand for safe and secure food with higher shelf life has been increased among people. Enzyme and microorganisms are critical factors in food deterioration, and their inactivation can enhance food safety. The inactivation of the enzymes and microorganisms can be carried out by both thermal (saturated steam, application of dry heat) and non-thermal processing (pulsed electric field, high-pressure processing, and ultrasound).

P. P. Sutar

paragsutar@gmail.com

1 Department of Food Process Engineering, National Institute of Technology Rourkela, Rourkela, Odisha, India 769008
Globally, garlic (Allium sativum L.) is widely used as food, spices, and folk medicine. It has numerous biological effects, including antimicrobial, anticancer, hypolipidemic, antioxidant, antithrombotic, and improves immune system (Kar et al., 2018; Wang et al., 2011). Garlic can be consumed in raw form or in processed form like garlic flex, garlic powder, garlic tablet, garlic paste, and garlic pickles. Fresh garlic is prone to spoilage due to its initial high moisture content and higher enzyme and microbial activities. Black mould rot and bacterial rot are the two major diseases developed in garlic during its storage. After harvesting, the black mould rot in whole garlic bulbs is caused due to Aspergillus niger. Aspergillus niger can cause otomycosis and is associated with nosocomial infections, especially in immune-compromised and transplanted patients (Kar et al., 2018). Recently, few COVID-19 
and Aspergillus niger co-infection cases and deaths have been reported (Trovato et al., 2021). Therefore, the whole garlic bulb is required to be sterilized to avoid the food born infections of Aspergillus niger in patients. Thermal processing like blanching is carried out to garlic bulbs to prevent such microbial spoilage and chemical deterioration as well as to increase the shelf life (Bozkir et al., 2018). However, food products undergo many physicochemical alterations during drying like volume shrinkage, discolouration, and case hardening. The enzymatic and non-enzymatic reactions, degradation of chlorophylls, and carotenoids lead to colour changes during drying. Often residual endogenous enzymes in dried vegetables cause quality changes over a period of time (Zhang et al., 2017).

For any garlic processing like making paste or powder, enzyme inactivation and microbial reduction are needed to produce stable and good quality products. Enzyme inactivation can be carried out by applying any suitable pretreatment or by blanching. In agricultural products, polyphenol oxidase (PPO) and peroxidase (POD) enzymes are associated with the browning process. When peeled garlic cloves are exposed to the ambient environment, they undergo undesirable quality changes like rapid browning (Fante \& Noreña, 2012). PPO is responsible for the appearance of brown substances due to hydroxylation of monophenols (monophenolase) and oxidation of o-diphenols to o-quinones (diphenolase), which subsequently polymerize to yield undesirable brown pigments in the presence of oxygen (Cao et al., 2018). POD enzyme also plays a crucial role in quality deterioration due to numerous biodegradation reactions, which lead to flavour loss and enzymatic browning since diphenols functions as reducing substrate in the enzymatic reaction promoting darkening of food products during processing and preservation (Jang \& Moon, 2011). In the food industry, a general thumb rule is that if peroxidase is inactivated, then a very low probability is that any other heat-resistant enzyme activity will be detected (GamboaSantos et al., 2012). Thermal treatment like blanching is the common pretreatment practice for enzyme inactivation and colour retention in drying. Usually, blanching is helpful for fruit and vegetable, where steam or hot water temperature is maintained at $75-95{ }^{\circ} \mathrm{C}$ for $1-10 \mathrm{~min}$. However, thermal treatment has limitations like loss of nutritional and sensory quality of food products, which is not desirable (Zhang et al., 2017). Many research studies reported the tolerance of POD and PPO enzymes to thermal processing, especially below $80^{\circ} \mathrm{C}$ (Yoruk \& Marshall, 2003). It has also been reported that energy transferred by ultrasound application may contribute to a decrease in thermal tolerance by PODs in fruit samples (Cruz et al., 2006). Therefore, applying pretreatments at relatively low temperatures than blanching temperatures can be a suitable alternative. Ultrasound can be useful as a blanching pretreatment for POD and PPO inactivation as the process can be carried out at relatively low temperatures. Currently, ultrasonic technology has been practiced in food processing because of cavitation, which is helpful in enzyme and microbial inactivation. During ultrasonication, enzyme inactivation occurs by cell lysis due to high temperature and pressure fluctuation using vibration energy (Yildiz \& Izli, 2019). Researchers have reported that ultrasound combined with thermal treatment increases enzyme inactivation and reduces processing time. Many research studies revealed endogenous enzymes in fruit and vegetables, including lemon pectinesterase, mushroom PPO, tomato juice watercress peroxidase, pectin methyl esterase, and polygalacturonase, and had been inactivated intensely by thermo-sonication. Ultrasound not only inactivates enzymes but also helpful in microorganism reduction. It has been reported that sonication induces cavity formation and the disperses of clumps of microorganisms, punctures cell wall, and modifies cellular activity, thus increasing cell sensitivity towards heat (Fernandes et al., 2008). Still, some research studies even found an increase in POD and PPO activity due to the application of ultrasonication. Silva et al., (2015) studied the effect of thermosonication on apple cube and apple juices and found out that a maximum decrease of $57 \%$ in PPO activity was observed at the highest power density $(3300 \mathrm{~W} / \mathrm{L})$ for $20 \mathrm{~min}$ at ambient temperature $23^{\circ} \mathrm{C}$ in a probe sonicator. A decrease in activity was observed among the apple juice sonicated at low power density and high power density. Even increase in PPO activity in apple cubes observed reaching a maximum relative activity of $138 \%$ at a power density of $2650 \mathrm{~W} / \mathrm{L}$ and then decreased at higher power densities ( $3300 \mathrm{~W} / \mathrm{L})$. But POD activity found to be increased due to ultrasound application (Silva et al., 2015). Another research study evaluated the use of ultrasound technology (US) alone and as a pre-treatment to thermal processing for inactivating/ sensitizing coconut water peroxidase (POD) and found that enzyme activity was reduced by $27 \%$ after $30 \mathrm{~min}(286 \mathrm{~W} / \mathrm{L}$, $20 \mathrm{kHz}$ ), demonstrating its high resistance (Rojas et al., 2017). Many processors utilize a heat treatment sufficient to inactivate peroxidase, one of the more stable enzymes present, and not incidentally, one of the enzymes whose activity is relatively easy to measure. It is reported that $90 \%$ inactivation of POD is sufficient to prevent any deterioration in food and recommended the same as the optimum level for blanching (Zheng $\& \mathrm{Lu}, 2011)$. However, in many cases, $90 \%$ POD enzyme inactivation could not be easily achieved by ultrasonication alone. Some studies revealed that romaine lettuce's sensory and nutritional quality was not affected much by high-intensity ultrasonication (Yu et al., 2016). Another study by (Zhang et al., 2019) reported a significant reduction in POD and PPO activities of pakchoi due to ultrasonication $(30 \mathrm{kHz})$ above $10 \mathrm{~min}$, combined with a modified atmosphere. Some research studies reported that the firmness of thermosonicated pepper and strawberries was equal or better retained than the firmness of heat-blanched samples at the same temperatures (Alexandre et al., 2011). 
Microwave is also effective as a pretreatment as it helps in inactivating enzymes and microorganisms. Inactivation of polyphenol oxidase and peroxidase in coconut water by microwave has been reported and found to be faster than conventional processes (Matsui et al., 2008). Another study reported the inactivation of polyphenol oxidase for mushrooms by microwave heating (Devece et al., 1999). Enzyme inactivation of tea by microwave heating retains higher vitamin $\mathrm{C}$ content and minimum storage loss than oven heating (Huang et al., 2007). Microwave was also found to be efficient technology to improve physicochemical, nutritional, and sensorial quality of kiwi fruit puree and faba beans pesto sauce over conventional pasteurization (Benlloch-Tinoco et al., 2012; Klug et al., 2018). A high-power short-time microwave pretreatment helps in the sudden rise of temperature in the product, leading to enzyme and microorganism inactivation (Zheng \& Lu, 2011). Nalawade et al. (2018) reported more than $90 \%$ of PPO and POD enzyme inactivation due to microwave dry blanching at $8.8 \mathrm{~W} / \mathrm{g}$ in $2.5 \mathrm{~min}$ as compared to $7.36 \mathrm{~W} / \mathrm{g}(3.0 \mathrm{~min})$ and $5.57 \mathrm{~W} / \mathrm{g}(4 \mathrm{~min})$. Microwave treatment at higher power density can inactivate enzymes by more than $90 \%$, but it results in undesirable high product temperature along with damaged texture (Nalawade et al., 2018; Rojas et al., 2017). In strawberry puree, the microwaves did not effectively inactivate PPO and POD enzymes above $80 \%$ even at $80{ }^{\circ} \mathrm{C}$ temperature (Marszałek et al., 2015). The uniform temperature rise in microwaves always has been a challenge in the food industry (Salazar-González et al., 2012). No research study has been reported on the combined effect of ultrasound and microwaves in enzyme and microbial inactivation in whole garlic bulb. Also, the application of ultrasonication prior to microwaves to achieve uniform heating in garlic bulbs as well as to enhance the overall efficacy of microwave pretreatment has not been reported by any researcher. Therefore, the research work was undertaken to study the individual and the combined effect of ultrasonication and microwave pretreatment on POD, PPO, and Aspergillus niger inactivation in whole garlic bulbs, as well as to increase efficacy of the microwave blanching-cum-black mould inactivation process by ultrasonication.

\section{Material and Methods}

\section{Raw Materials}

Garlic bulbs (Allium sativum) of uniform size, colour, and without injury and infections were bought from a local market of Rourkela, Odisha (India) and were stored at room temperature $\left(22 \pm 2{ }^{\circ} \mathrm{C}\right)$ till further use. The initial moisture content was estimated by the hot air oven method (AOAC, 1984). The initial moisture content of raw garlic was found to be 1.85 to $1.95 \mathrm{~g}$ water $\mathrm{g}^{-1}$ dry matter. Garlic bulb had 3 axis $(l=30.52 \pm 1.89 \mathrm{~mm}$, $\mathrm{b}=29.77 \pm 2.67 \mathrm{~mm}, \mathrm{t}=36.42 \pm 4.43 \mathrm{~mm}$ ) having equivalent diameter $32.06 \pm 2.59 \mathrm{~mm}$ with sphericity ranging from 0.85 to 0.98 . The weight of garlic bulbs varied from $20 \pm 2 \mathrm{~g}$ to $26 \pm 4 \mathrm{~g}$, depending on their size.

\section{Experimental Procedure}

The whole garlic bulbs were subjected to ultrasound and high-power-short-time-microwave pretreatment. The ultrasound power density, bath temp, and treatment time were varied, whereas, in microwave pretreatment, the microwave power density and heating time were varied. The effects of both the pretreatment on the activities of POD, and PPO, and Aspergillus niger reduction were studied.

\section{Ultrasound Pretreatment}

A $100 \mathrm{~W} / 40 \mathrm{kHz}$ ultrasonic bath (Labman Ultrasonic water bath, Model: LMUC-3, India) was used in the experiments. The bath volume was $3 \mathrm{~L}$. As the power of the ultrasonicator was $100 \mathrm{~W}$ for a bath volume of $3 \mathrm{~L}$, the ultrasound power density was calculated by dividing the $100 \mathrm{~W}$ by the amount of water filled in the bath (L). Ultrasound application with bath temperature 40 to $60{ }^{\circ} \mathrm{C}$ has been proved to be effective against the PPO and POD inactivation (Gamboa-Santos et al., 2012). The ultrasonic bath temperature was noted from an already existing temperature controller fitted to the ultrasonication bath. The garlic bulbs achieved the same bath temperature. A bath-type ultrasonicator was selected for garlic pretreatment, aiming for a further scale-up of the process for the garlic processing industry. The experiments were carried out according to a five-level, three-variable central composite design (CCD). The levels of ultrasound power density ( 45 to $65 \mathrm{~W} / \mathrm{L}$ ), the temperature of ultrasonic water bath $\left(40\right.$ to $\left.60^{\circ} \mathrm{C}\right)$, and ultrasonication duration (20 to $40 \mathrm{~min}$ ) were selected after studying the results published in the literature (Gamboa-Santos et al., 2012; Mothibe et al., 2014; Rodrigues \& Fernandes, 2007) and preliminary trials. For $38,45,55,65$, and $72 \mathrm{WL}^{-1}$ ultrasound power density, the volume of water in the bath $(\mathrm{L})$ was varied to get the predetermined ultrasound power density with the ultrasound power of $100 \mathrm{~W}$. In all experiments, $100 \mathrm{~g} \pm 2 \mathrm{~g}$ of garlic bulbs (4-5 numbers) were immersed in the ultrasound water baths set with a predetermined power density (W/L). On an industrial scale, more garlic with less amount of water can also be used to have higher pretreatment capacity. 


\section{Microwave Pretreatment}

Whole garlic bulbs were treated in a microwave oven (Samsung CE73JD-B/XTL 21L Convection, India) by varying power density from 1 to $4 \mathrm{~W} / \mathrm{g}$ and treatment duration from 40 to $180 \mathrm{~s}$ using a central composite rotatable design (CCRD). The manufacturer rated output power of the microwave oven was $800 \mathrm{~W}$. As the microwave works on the principle of volumetric heating, the microwave power density (W/g) was calculated by dividing the actual microwave power output by the oven at a particular power setting by the weight of the garlic bulbs. The real microwave power generated by magnetron was determined using International Microwave Power Institute (IMPI) 2-L water method (Chamchong \& Datta, 1999). The microwave power density was estimated by the amount of microwave power (W) available per product's unit mass (g). The efficiency test indicated $82 \%$ efficiency of the oven in our experiments. The range of independent variables was selected by analysing the data of the preliminary trials and published literature (Mothibe et al., 2014; Pankaj et al., 2018; Zheng \& Lu, 2011). For 2.5, 4, 4.62, 1, $0.378 \mathrm{Wg}^{-1}$ microwave power densities, 59.20, 37, 32.03, 148, $391 \mathrm{~g}$ of garlic mass was treated. The total garlic bulb used in the experiment varies from 1 to 15 as the power density varied from 4.62 to 0.378 . The weight of each garlic bulb varies from 20-26 g depending on the size of the garlic bulb. The temperature profile of garlic was obtained by an infrared thermometer $\left(-50\right.$ to $380^{\circ} \mathrm{C}$, IRL380, KUSAMMECO, India) at every $5 \mathrm{~min}$ time interval during heating. The front door of microwave oven was opened, and the infrared thermometer was projected at three different points on the surface of the whole garlic bulbs and the average value was recorded.

\section{Specific Energy Consumption}

The specific energy consumption can be defined as the energy required to treat the unit mass of a product using any treatment. The specific energy consumption of ultrasonication $\left(S E C_{u s}\right)$ can be determined by adding the specific energy consumption due to pretreatment and specific energy required to raise the bath temperature of the ultrasonicator and is given in Eq. (1) (Abdoli et al., 2018).

$S E C_{u s}=\frac{P t_{1}}{m_{u s}}+\frac{P t_{2}}{m_{u s}}$

The specific energy consumption $\left(S E C_{m w}\right)$ due to a microwave can be obtained through the following equation (TorkiHarchegani et al., 2016).

$S E C_{m w}=\frac{P_{m} t_{m}}{m_{m w}}$ where $P_{m}, t_{m}$, and $m_{m w}$ are operating powers of microwave, treatment time, and mass of the treated sample, respectively, and the final specific energy consumption is expressed in Watt-h $\mathrm{g}^{-1}$.

Total SEC for combined microwave and US pretreatment was obtained from the following equation: (Jahanbakhshi et al., 2020)

$S E C_{\text {total }}=S E C_{u s}+S E C_{m w}$

\section{Enzyme Analysis}

\section{Enzyme Extracts Preparation}

Ultrasound-treated garlic bulbs with $0.1 \mathrm{M}$ sodium phosphate buffer ( $\mathrm{pH} 7$ ) were ground in the 1:3 ratio. The garlic buffer mixture was filtered in filter paper and centrifuged at $5100 \mathrm{~g} \mathrm{rcf}$ (RC-5B PLUS, Sorvall) at $4{ }^{\circ} \mathrm{C}$ for $20 \mathrm{~min}$. The supernatants obtained from the centrifuge were analysed.

\section{Peroxidase Activity}

POD activity of garlic was determined by spectrophotometer using Zhang et al. (2017) method with slight modification. The peroxidase enzyme inactivation in the garlic sample can be expressed $E_{p o}$ in percentage and can be calculated by using Eq. (4):

$E_{p o}=\left(1-\frac{A_{\theta p o}}{A_{\text {opo }}}\right) \times 100$

where $A_{\theta p o}$ and $A_{0 p o}$ are the peroxidase enzyme activity of the treated and untreated garlic, respectively.

\section{Polyphenoloxidase Activity}

The PPO activity of garlic was determined using $0.1 \mathrm{M}$ catechol as substrate, and OD was measured at $411 \mathrm{~nm}$ using UV-visible spectrophotometer (UV-1800, Shimadzu, Japan) (Nalawade et al., 2018). The percentage of PPO inactivation can be determined by the following equation:

$E_{p p}=\left(1-\frac{A_{\theta p p}}{A_{o p p}}\right) \times 100$

where $E_{p p}, A_{\theta p o}$, and $A_{0 p o}$ are the percentage of PPO inactivation, the PPO activity of the treated and untreated garlic, respectively. 


\section{Aspergillus Niger Estimation}

Total Aspergillus niger count of raw and pre-treated garlic was estimated in a biological safety cabinet (1300 Series A2, Thermo Fisher Scientific, SuZhou, China). Ultrasoundtreated garlic cloves were pulverized and aseptically placed in a $0.1 \%$ sterile saline water followed by 2 min of vortexing. Potato dextrose agar (Himedia, India) mixed with distilled water in 1:22 $\mathrm{g} \mathrm{L}^{-1}$ ratio was chosen as the culture media and was sterilized at 15 psi pressure and $121{ }^{\circ} \mathrm{C}$ temperature for $15 \mathrm{~min}$ in an autoclave and was allowed to cool to $50{ }^{\circ} \mathrm{C}$. Antibiotic supplement (Chloramphenicol) mixed with ethanol in 1:40 ratio was added to agar media for the selective isolation of yeasts and mould. The agar media were then poured into the pre-sterilized petri plates for solidification. Dense cell culture was reduced to usable concentration by serial dilution. Aseptically, $0.1 \mathrm{~mL}$ of the sample was added to the solidified agar petri plates and the petri plates were sealed with parafilm and placed in an incubator at $27{ }^{\circ} \mathrm{C}$ for 24 to $48 \mathrm{~h}$. The natural Aspergillus niger present in the garlic sample was taken into account for log reduction calculations. The garlic bulbs were procured in a lot and stored in the refrigerator for one week before the pretreatment. The initial count of Aspergillus niger in the garlic lot was found to be in the range of $2.3 \times$ $10^{4}$ to $3 \times 10^{4}$. The samples were removed from the refrigerator, and Aspergillus niger enumeration was carried out after each treatment. The average data of three replicates were used for the calculation of log reduction.

\section{Statistical Analysis and Optimization}

The ultrasonic and microwave experiments were designed using a Central Composite Design (CCD) (Table 1). Experimental data were analysed by a commercial statistical package Design Expert Software (Stat-Ease, DX10), and a quadratic model is fitted to the experimental data for regression analysis and optimization. The response function was partitioned into linear interactive components as given below:

$R_{k}=q_{o}+\sum_{i=1}^{3} q_{i} X_{i}+\sum_{i=1}^{3} q_{i i} X_{i}^{2}+\sum_{i \neq j=1}^{3} q_{i j} X_{i} X_{j}$

where $\mathrm{R}_{\mathrm{k}}$ is the response, $q_{o}$ and $q_{i}$ are the constant and linear regression coefficients. To find out the effects of independent variables, ANOVA was used. The model adequacy was tested by checking $R^{2}$ and lack of fit. Optimization of parameters was carried out by using the response surface methodology.
Table 1 Experimental condition for the three variables, five-level central composite designs (CCD) matrix with responses for ultrasonication pretreatment

\begin{tabular}{lllllll}
\hline $\begin{array}{l}\text { US PD } \\
\mathrm{WL}^{-1}\end{array}$ & $\begin{array}{l}\text { Bath temp } \\
{ }^{\circ} \mathrm{C}\end{array}$ & $\begin{array}{l}\text { Duration } \\
\text { min }\end{array}$ & $\begin{array}{l}\text { FT } \\
{ }^{\circ} \mathrm{C}\end{array}$ & $\begin{array}{l}\text { \% POD } \\
\text { inactivation } \\
\text { (mean } \pm \mathrm{SD})\end{array}$ & $\begin{array}{l}\text { \%PPO } \\
\text { inactivation } \\
\text { (mean } \pm \mathrm{SD} \text { ) }\end{array}$ & $\begin{array}{l}\text { Aspergillus niger } \\
\text { log reduction } \\
\text { (mean } \pm \mathrm{SD})\end{array}$ \\
\hline 72 & 50 & 30 & 63 & $47.08 \pm 1.42$ & $53.38 \pm 0.11$ & $2.30 \pm 0.12$ \\
55 & 33 & 30 & 48 & $22.19 \pm 1.94$ & $32.97 \pm 1.62$ & $1.22 \pm 0.09$ \\
55 & 50 & 30 & 60 & $45.25 \pm 2.84$ & $55.70 \pm 2.01$ & $2.50 \pm 0.21$ \\
38 & 50 & 30 & 58 & $34.58 \pm 2.18$ & $10.85 \pm 0.95$ & $1.82 \pm 0.18$ \\
45 & 60 & 40 & 70 & $77.51 \pm 2.19$ & $68.74 \pm 0.93$ & $2.30 \pm 0.02$ \\
65 & 60 & 40 & 71 & $79.60 \pm 0.39$ & $88.77 \pm 0.06$ & $2.60 \pm 0.22$ \\
55 & 50 & 30 & 61 & $55.25 \pm 1.12$ & $61.11 \pm 0.26$ & $2.00 \pm 0.06$ \\
55 & 67 & 30 & 73 & $85.71 \pm 1.62$ & $88.77 \pm 0.25$ & $2.60 \pm 0.11$ \\
55 & 50 & 30 & 60 & $56.21 \pm 0.49$ & $66.51 \pm 1.80$ & $1.50 \pm 0.08$ \\
65 & 60 & 20 & 66 & $44.35 \pm 1.87$ & $38.10 \pm 0.15$ & $2.60 \pm 0.16$ \\
45 & 60 & 20 & 63 & $62.04 \pm 2.42$ & $61.48 \pm 0.37$ & $2.30 \pm 0.03$ \\
55 & 50 & 30 & 59 & $50.00 \pm 1.30$ & $53.11 \pm 2.60$ & $2.30 \pm 0.12$ \\
65 & 40 & 40 & 57 & $57.14 \pm 1.03$ & $57.14 \pm 0.08$ & $1.82 \pm 0.16$ \\
55 & 50 & 30 & 61 & $48.21 \pm 0.65$ & $65.50 \pm 0.30$ & $1.80 \pm 0.10$ \\
55 & 50 & 47 & 67 & $65.40 \pm 1.12$ & $88.65 \pm 0.32$ & $2.60 \pm 0.06$ \\
45 & 40 & 20 & 49 & $24.09 \pm 0.31$ & $6.91 \pm 0.18$ & $1.30 \pm 0.18$ \\
65 & 40 & 20 & 51 & $18.07 \pm 0.59$ & $28.82 \pm 0.34$ & $1.42 \pm 0.02$ \\
45 & 40 & 40 & 56 & $44.37 \pm 0.43$ & $24.81 \pm 1.10$ & $1.56 \pm 0.14$ \\
55 & 50 & 30 & 60 & $58.71 \pm 0.56$ & $58.21 \pm 1.10$ & $2.40 \pm 0.06$ \\
55 & 50 & 13 & 53 & $53.78 \pm 2.23$ & $31.34 \pm 2.54$ & $1.48 \pm 0.19$ \\
\hline
\end{tabular}

The SD is the standard deviation which was calculated from three replications 


\section{Perturbation Analysis}

The effect of independent parameters was analysed from the perturbation analysis. The variable ranges were chosen from -1 and +1 at 0.5 intervals, where other variables were maintained at 0 . The steep slope shows the higher sensitivity, and a relatively flat line indicates less sensitivity of response to the variable.

\section{Scanning Electron Microscopy}

A cut-section of tissue from the inner part of the ultrasound and microwave-treated and untreated garlic sample was subjected to a scanning electron microscope (JSM-6480LV, JEOL, Germany) for microscopical imaging. Before microscopy, the moisture was removed from the garlic at low temperature and the garlic samples were cut transversely by a sharp knife. The cut pieces of untreated and treated garlic samples were fixed on a specimen stub with double-sided sticky tape. The samples were coated with platinum and examined at an accelerating voltage of $15 \mathrm{kV}$, and micrographs were taken for each sample at $\times 200$ magnifications.

\section{Results and Discussions}

Effect of ultrasound power density, bath temperature, and duration on final water bath temperature, POD, and PPO activity and Aspergillus niger inactivation.

The responses collected in the US pretreatment are given in Table 1. The moisture content of US-treated gar-

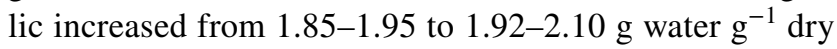
matter. The ANOVA showed the effect of the independent variables $(p \leq 0.05)$ on final ultrasonic bath temperature and is given in Table 2. The final ultrasound bath temperature (FT) was significantly $(p \leq 0.01)$ affected by ultrasound power density, initial bath temperature, and duration of ultrasonication. The ambient water temperature was $27^{\circ} \mathrm{C}$ during the experiments. The highest temperature rise was observed when the initial bath temperature was $66.81{ }^{\circ} \mathrm{C}$ with $55 \mathrm{WL}^{-1}$ ultrasound power density for 30 min duration. The experimental data were fitted to quadratic model Eq. (6), and the developed correlation is given below by eliminating non-significant terms:

$F T=8.818+0.026 P+0.569 \theta+0.655 t$

All the independent variables (ultrasound power density, bath temperature, and duration) were positively correlated with the final water bath temperature. The $\mathrm{R}^{2}$ and F-value of the regression model were 0.99 and 125.17 , which showed that the quadratic model is significant. The "predicted- $\mathrm{R}^{2}$, and " adjusted- $\mathrm{R}^{2}$," values were 0.99 and 0.98 , respectively.
The very low difference between adjusted and predicted $\mathrm{R}^{2}$ values indicated a realistic agreement. The model was found to be highly significant $(p \leq 0.01)$ and the lack of fit was non-significant $(p>0.05)$, with all the independent variables significantly contributing to the $F T$. The perturbation curve (Fig. 1) shows that the initial bath temperature highly impacted the final bath temperature, followed by treatment duration and ultrasound power density. An increase in power density and time of ultrasonication increased the energy input, resulting in an increase in temperature that promotes enzyme inactivation.

The effect of sonication on peroxidase POD and PPO activity was studied. POD is highly thermo-stable, and after POD inactivation, a very low probability of any other enzymatic activity presence will be there (Shirkole et al., 2020). ANOVA revealed that ultrasound power density, bath temperature, and ultrasonic duration significantly $(p \leq 0.01)$ affected PPO activities, whereas only the bath temperature and time of sonication were found to be significantly effective against POD activity and Aspergillus niger reduction. Costa et al. (2013) showed no inactivation effect of ultrasonication on PPO in pineapple juice at $54{ }^{\circ} \mathrm{C}$. Also, they observed that at low ultrasonic power levels $\left(75 \mathrm{~W} / \mathrm{cm}^{2}\right)$, enzyme release happens, and at higher power levels, denaturation of protein and cell wall occurs. Enzyme inactivation takes place when the rate of enzyme release overcomes by the rate of enzyme denaturation. POD activity was reduced by $22-85 \%$, and PPO activity reduced by $6-88 \%$ during the entire experimental range. The perturbation analysis (Figs. 2 and 3) showed that initial water bath temperature highly affected the enzyme activity followed by ultrasonic duration and power density which might be due to the rise in final water bath temperature from $48^{\circ}$ to $73^{\circ} \mathrm{C}$. The significant reduction in POD activity might be due to higher temperature rise, which activated the reaction of hydrogen or hydroxyl radicals formed with the protein backbone leading to protein instability by obstructing the active sites, which lead to enzyme aggregation (Rokhina et al., 2009). Ultrasonic power density did not have a significant effect on POD reduction. Some researchers reported that in some cases, specific ultrasound effects such as cavitation promoted POD activity (Tiwari et al., 2008).

Reduction in POD and PPO followed a similar trend, but in most cases, the degree of PPO inactivation was higher, as PPO was more thermo-labile. All the independent variables had a positive correlation with \% POD and \% PPO inactivation. Several researchers reported that complete inactivation of POD was not achieved at a temperature below $80{ }^{\circ} \mathrm{C}$ (Dabir \& Ananthanarayan, 2017; Etzbach et al., 2019; Saeeduddin et al., 2015). This might be due to the characteristics of an enzyme that makes it thermo-stable because of its origin and the isoenzymes contained in it (Liu et al., 
Table 2 ANOVA table for FT, POD, PPO, and

Aspergillus niger inactivation in ultrasonication pretreatment

\begin{tabular}{|c|c|c|c|c|c|c|}
\hline Source & $\begin{array}{l}\text { Sum of } \\
\text { Squares }\end{array}$ & $\mathrm{df}$ & $\begin{array}{l}\text { Mean } \\
\text { Square }\end{array}$ & $\begin{array}{l}\mathrm{F} \\
\text { Value }\end{array}$ & $\begin{array}{l}\mathrm{p} \text {-value } \\
\text { Prob }>\mathrm{F}\end{array}$ & \\
\hline & & & FT & & & \\
\hline Model & 910.12 & 9 & 101.12 & 125.17 & $<0.0001$ & significant \\
\hline A-US PD & 17.39 & 1 & 17.39 & 21.52 & 0.0009 & \\
\hline B-Bath temp & 718.31 & 1 & 718.31 & 889.10 & $<0.0001$ & \\
\hline C-Duration & 172.56 & 1 & 172.56 & 213.59 & $<0.0001$ & \\
\hline $\mathrm{AB}$ & 0.13 & 1 & 0.13 & 0.15 & 0.7023 & \\
\hline $\mathrm{AC}$ & 1.13 & 1 & 1.13 & 1.39 & 0.2653 & \\
\hline $\mathrm{BC}$ & 0.13 & 1 & 0.13 & 0.15 & 0.7023 & \\
\hline $\mathrm{A}^{2}$ & 0.22 & 1 & 0.22 & 0.28 & 0.6104 & \\
\hline $\mathrm{B}^{2}$ & 0.22 & 1 & 0.22 & 0.28 & 0.6104 & \\
\hline $\mathrm{C}^{2}$ & 0.039 & 1 & 0.039 & 0.049 & 0.8297 & \\
\hline Residual & 8.08 & 10 & 0.81 & & & \\
\hline Lack of Fit & 5.25 & 5 & 1.05 & 1.85 & 0.2577 & not significant \\
\hline Pure Error & 2.83 & 5 & 0.57 & & & \\
\hline Cor Total & 918.20 & 19 & & & & \\
\hline $\mathrm{R}^{2}$ & 0.99 & & & & & \\
\hline Adj $R^{2}$ & 0.98 & & & & & \\
\hline Pred $R^{2}$ & 0.95 & & & & & \\
\hline C.V. $\%$ & 1.49 & & & & & \\
\hline SD & 0.90 & & & & & \\
\hline \multicolumn{7}{|c|}{$\%$ POD inactivation } \\
\hline Model & 5641.12 & 9 & 626.79 & 10.59 & 0.0005 & significant \\
\hline A-US PD & 10.87 & 1 & 10.87 & 0.18 & 0.6774 & \\
\hline B-Bath temp & 3762.08 & 1 & 3762.08 & 63.56 & $<0.0001$ & \\
\hline C-Duration & 1230.30 & 1 & 1230.30 & 20.79 & 0.0010 & \\
\hline $\mathrm{AB}$ & 62.38 & 1 & 62.38 & 1.05 & 0.3288 & \\
\hline $\mathrm{AC}$ & 186.05 & 1 & 186.05 & 3.14 & 0.1066 & \\
\hline $\mathrm{BC}$ & 9.29 & 1 & 9.29 & 0.16 & 0.7003 & \\
\hline$A^{2}$ & 263.01 & 1 & 263.01 & 4.44 & 0.0612 & \\
\hline $\mathrm{B}^{2}$ & 1.94 & 1 & 1.94 & 0.033 & 0.8601 & \\
\hline$C^{2}$ & 80.31 & 1 & 80.31 & 1.36 & 0.2711 & \\
\hline Residual & 591.88 & 10 & 59.19 & & & \\
\hline Lack of Fit & 480.35 & 5 & 96.07 & 4.31 & 0.0675 & not significant \\
\hline Pure Error & 111.53 & 5 & 22.31 & & & \\
\hline Cor Total & 6233.00 & 19 & & & & \\
\hline $\mathrm{R}^{2}$ & 0.90 & & & & & \\
\hline Adj $R^{2}$ & 0.82 & & & & & \\
\hline Pred $\mathrm{R}^{2}$ & 0.39 & & & & & \\
\hline C.V. $\%$ & 14.91 & & & & & \\
\hline SD & 7.69 & & & & & \\
\hline \multicolumn{7}{|c|}{$\%$ PPO inactivation } \\
\hline Model & $10,453.05$ & 9 & 1161.45 & 22.90 & $<0.0001$ & significant \\
\hline A-US PD & 1097.31 & 1 & 1097.31 & 21.64 & 0.0009 & \\
\hline B-Bath temp & 3983.89 & 1 & 3983.89 & 78.56 & $<0.0001$ & \\
\hline C-Duration & 2944.58 & 1 & 2944.58 & 58.07 & $<0.0001$ & \\
\hline $\mathrm{AB}$ & 414.58 & 1 & 414.58 & 8.18 & 0.0170 & \\
\hline $\mathrm{AC}$ & 362.21 & 1 & 362.21 & 7.14 & 0.0234 & \\
\hline $\mathrm{BC}$ & 17.14 & 1 & 17.14 & 0.34 & 0.5739 & \\
\hline $\mathrm{A}^{2}$ & 1627.40 & 1 & 1627.40 & 32.09 & 0.0002 & \\
\hline $\mathrm{B}^{2}$ & 3.05 & 1 & 3.05 & 0.060 & 0.8112 & \\
\hline
\end{tabular}


Table 2 (continued)

\begin{tabular}{|c|c|c|c|c|c|c|}
\hline Source & $\begin{array}{l}\text { Sum of } \\
\text { Squares }\end{array}$ & df & $\begin{array}{l}\text { Mean } \\
\text { Square }\end{array}$ & $\begin{array}{l}\mathrm{F} \\
\text { Value }\end{array}$ & $\begin{array}{l}\text { p-value } \\
\text { Prob }>F\end{array}$ & \\
\hline $\mathrm{C}^{2}$ & 8.53 & 1 & 8.53 & 0.17 & 0.6903 & \\
\hline Residual & 507.12 & 10 & 50.71 & & & \\
\hline Lack of Fit & 364.09 & 5 & 72.82 & 2.55 & 0.1641 & not significant \\
\hline Pure Error & 143.03 & 5 & 28.61 & & & \\
\hline Cor Total & 10960.17 & 19 & & & & \\
\hline $\mathrm{R}^{2}$ & 0.95 & & & & & \\
\hline Adj $R^{2}$ & 0.91 & & & & & \\
\hline Pred $\mathrm{R}^{2}$ & 0.71 & & & & & \\
\hline C.V. $\%$ & 13.68 & & & & & \\
\hline SD & 7.12 & & & & & \\
\hline \multicolumn{7}{|c|}{ Aspergillus niger log reduction } \\
\hline Model & 3.48 & 9 & 0.39 & 4.00 & 0.0208 & significant \\
\hline A-US PD & 0.24 & 1 & 0.24 & 2.43 & 0.1497 & \\
\hline B-Bath temp & 2.65 & 1 & 2.65 & 27.42 & 0.0004 & \\
\hline C-Duration & 0.47 & 1 & 0.47 & 4.85 & 0.0522 & \\
\hline $\mathrm{AB}$ & $5.718 \times 10^{-3}$ & 1 & $5.718 \times 10^{-3}$ & 0.059 & 0.8127 & \\
\hline $\mathrm{AC}$ & $2.391 \times 10^{-3}$ & 1 & $2.391 \times 10^{-3}$ & 0.025 & 0.8782 & \\
\hline $\mathrm{BC}$ & 0.054 & 1 & 0.054 & 0.56 & 0.4718 & \\
\hline$A^{2}$ & $1.422 \times 10^{-3}$ & 1 & $1.422 \times 10^{-3}$ & 0.015 & 0.9058 & \\
\hline $\mathrm{B}^{2}$ & 0.057 & 1 & 0.057 & 0.59 & 0.4585 & \\
\hline $\mathrm{C}^{2}$ & $3.726 \times 10^{-3}$ & 1 & $3.726 \times 10^{-3}$ & 0.039 & 0.8483 & \\
\hline Residual & 0.97 & 10 & 0.097 & & & \\
\hline Cor Total & 4.44 & 19 & & & & \\
\hline Lack of Fit & 0.22 & 5 & 0.044 & 0.29 & 0.8989 & not significant \\
\hline Pure Error & 0.75 & 5 & 0.15 & & & \\
\hline $\mathrm{R}^{2}$ & 0.78 & & & & & \\
\hline Adj $R^{2}$ & 0.59 & & & & & \\
\hline Pred $\mathrm{R}^{2}$ & 0.38 & & & & & \\
\hline C.V. $\%$ & 15.37 & & & & & \\
\hline SD & 0.31 & & & & & \\
\hline
\end{tabular}

2013). The quadratic model was fitted to the \% of POD and PPO inactivation, and the non-significant terms were neglected and the developed correlation is given below:

$\%$ POD inactivation $=-175.935+4.738 P+3.152 \theta-2.581 t$ non-significant $(p>0.05)$. Perturbation graph (Fig. 4) and ANOVA showed that bath temperature was found to be a significant factor in Aspergillus niger inactivation than ultrasonication. Ultrasound power density and sonication duration although increased the Aspergillus niger inactiva-

$\% P P O$ inactivation $=-523.482+14.166 P+5.689 \theta-2.503 t-0.072 P \theta+0.067 P t-0.106 P^{2}$

The $\mathrm{R}^{2}$ of the linear regression model for POD and PPO inactivation was found to be 0.91 and 0.95 , respectively. The

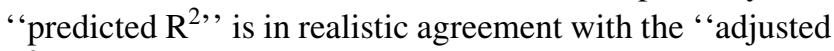
$\mathrm{R}^{2 \text { " }}$ as the difference was low. Both the models were found to be significant $(p \leq 0.01)$ with a non-significant $(p>0.05)$ lack of fit.

The linear model was fitted to the Aspergillus niger inactivation data and the model was found to be highly significant $(p \leq 0.01)$ and lack of fit was found to be tion, but did not affect significantly. The average log reduction in Aspergillus niger was found to be in the 1.22 to 2.60 range when the final temperature raised from $48^{\circ}$ to $73^{\circ}$ C. The lowest Aspergillus niger reduction occurred at 55 $\mathrm{WL}^{-1}$ ultrasound power density with an initial bath temperature of $33.18{ }^{\circ} \mathrm{C}$ for 30 min duration, where final bath temperature was raised to $48{ }^{\circ} \mathrm{C}$. The highest log reduction of 2.60 was achieved at $73^{\circ} \mathrm{C} F T$ where operating parameters were $55 \mathrm{WL}^{-1}$ power density at $66.81^{\circ} \mathrm{C}$ initial bath 


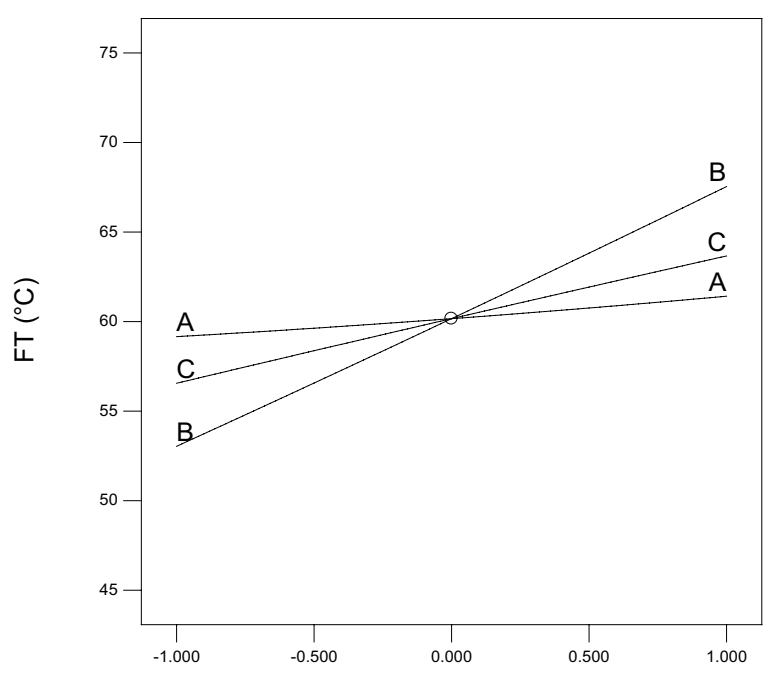

Deviation from Reference Point (Coded Units)

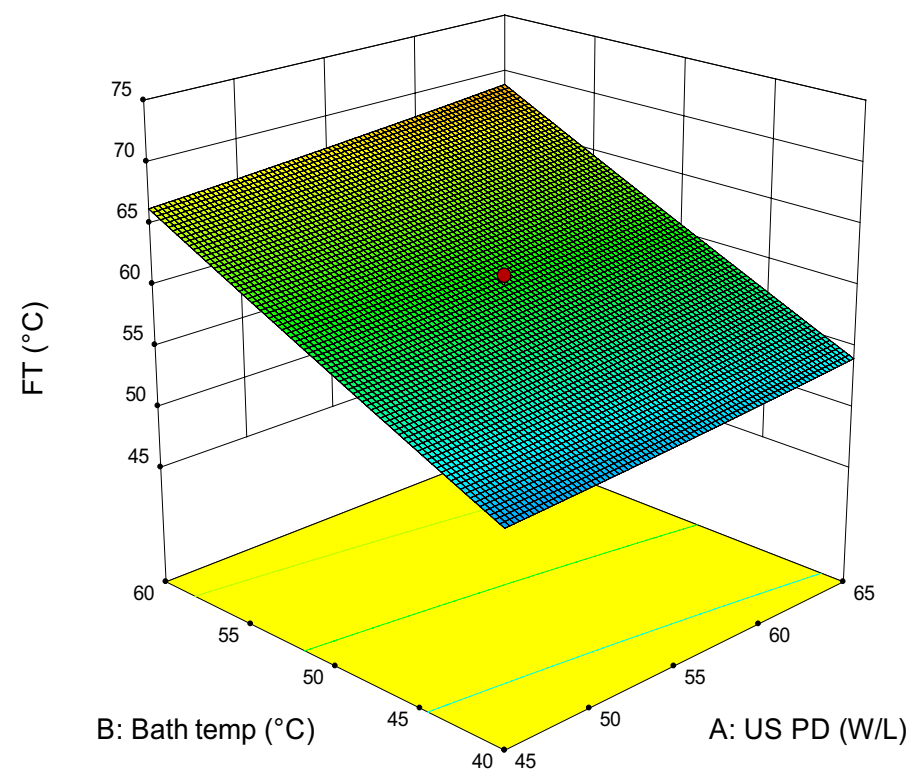

Fig. 1 Effect of bath temperature, US power density (PD), and duration on final temperature

temperature and 30 min sonication time. The increase in final temperature and duration of sonication would have been effective for higher Aspergillus niger reduction. Park et al. (2021) carried the hurdle treatment (thermosonication $+1 \%$ Ascorbic acid) on soft persimmon juice. They found that thermo-sonication at $50{ }^{\circ} \mathrm{C}$ for $30 \mathrm{~min}$ with $1 \%$ ascorbic acid addition resulted in more than 5-log pathogen reduction in soft persimmon juice. They reported that thermosonication was more effective after 30 min of treatment. During the ultrasonication experiment, a quadratic model fitted to Eq. (6) to the Aspergillus niger inactivation and correlation was developed, which is given below by eliminating non-significant terms:

Aspergillus niger inactivation $=-3.633+0.117 \theta+0.060 t$
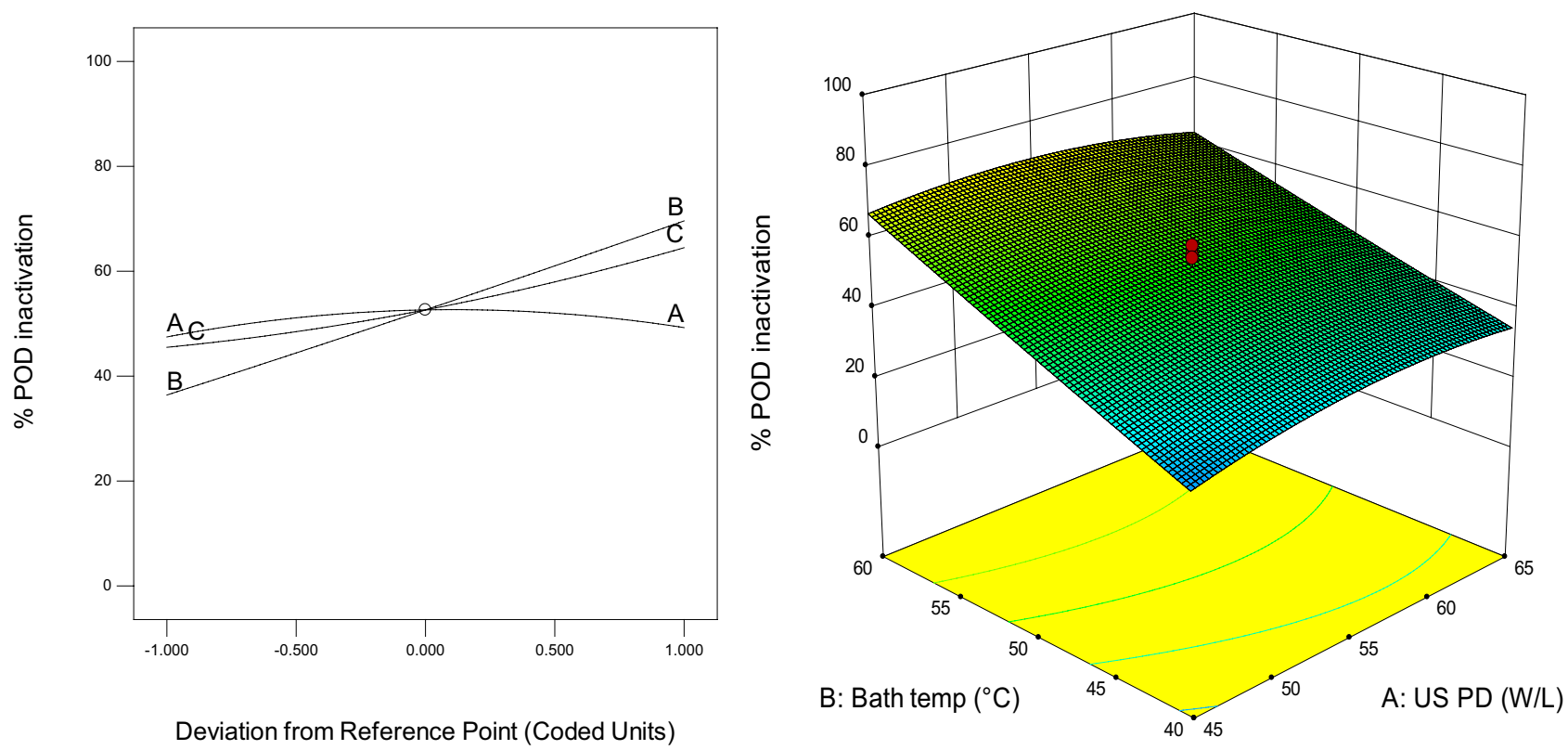

Fig. 2 Effect of bath temperature, US PD, and duration on \% POD inactivation 

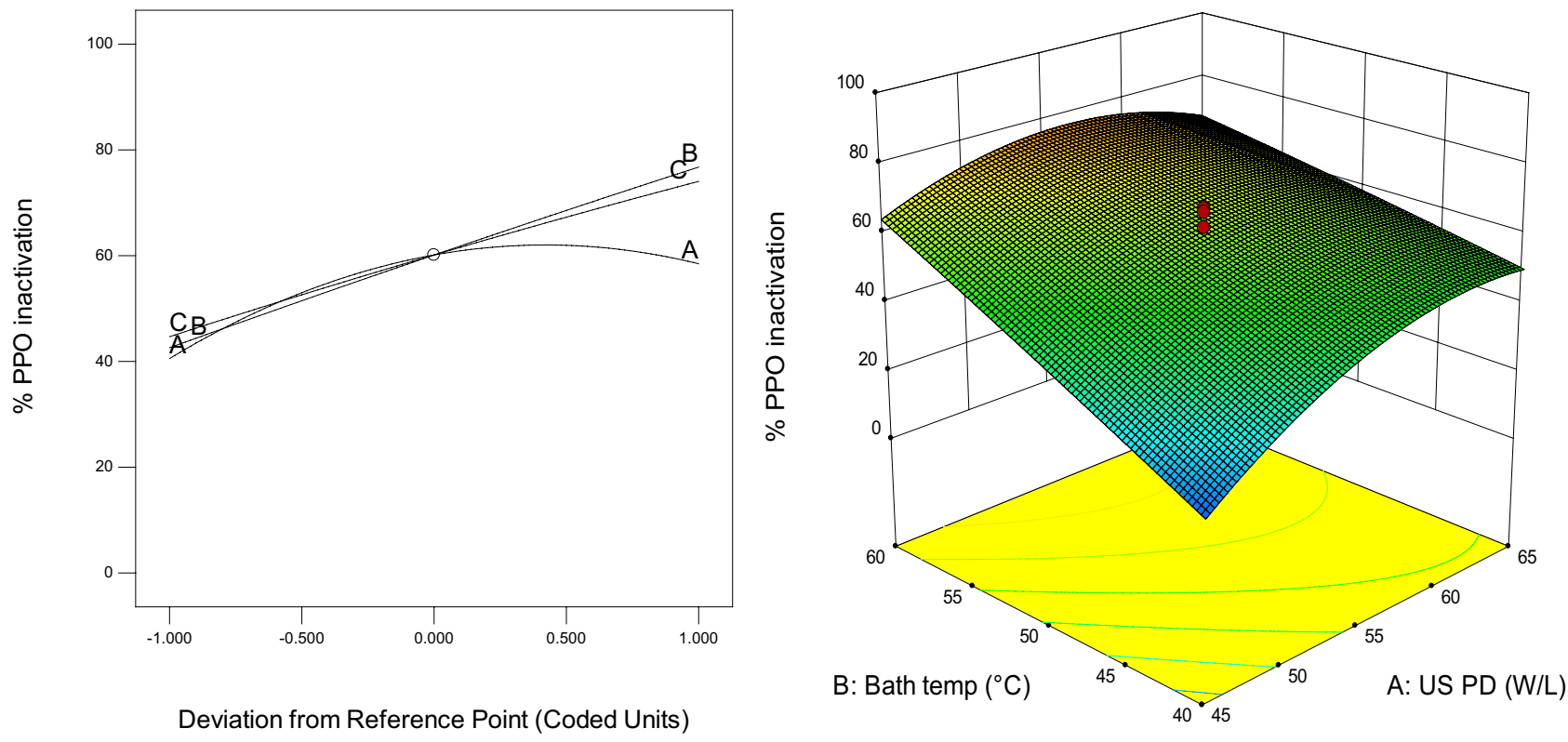

Fig. 3 Effect of bath temperature, US PD, and duration on \% PPO inactivation

All the independent variables had positive impacts on Aspergillus niger inactivation. The coefficient of determination $\left(\mathrm{R}^{2}\right)$ for the regression model was found to be 0.78 .

\section{Optimization of Ultrasound Pretreatment}

The optimization conditions for ultrasound pretreatment were chosen by taking ultrasound power density, bath temperature, duration, and the final temperature in the range with a maximum possible enzymes and microbes inactivation
$(+++$ level). As the treatment duration was higher in the ultrasonication process, it was decided to minimize the temperature of the water bath during the optimization process to preserve the micronutrient loss. The $\mathrm{L}, \mathrm{a}, \mathrm{b}$ colour analysis of treated garlic was carried out using Hunter colour lab, and the colour change was found to be non-significant. Therefore, it was removed from the optimization. The optimum conditions for ultrasound pretreatment for garlic were found to be $58.43 \mathrm{WL}^{-1}$ ultrasound power density, initial bath temperature of $60^{\circ} \mathrm{C}$ and $40 \mathrm{~min}$ ultrasonication duration with 0.97
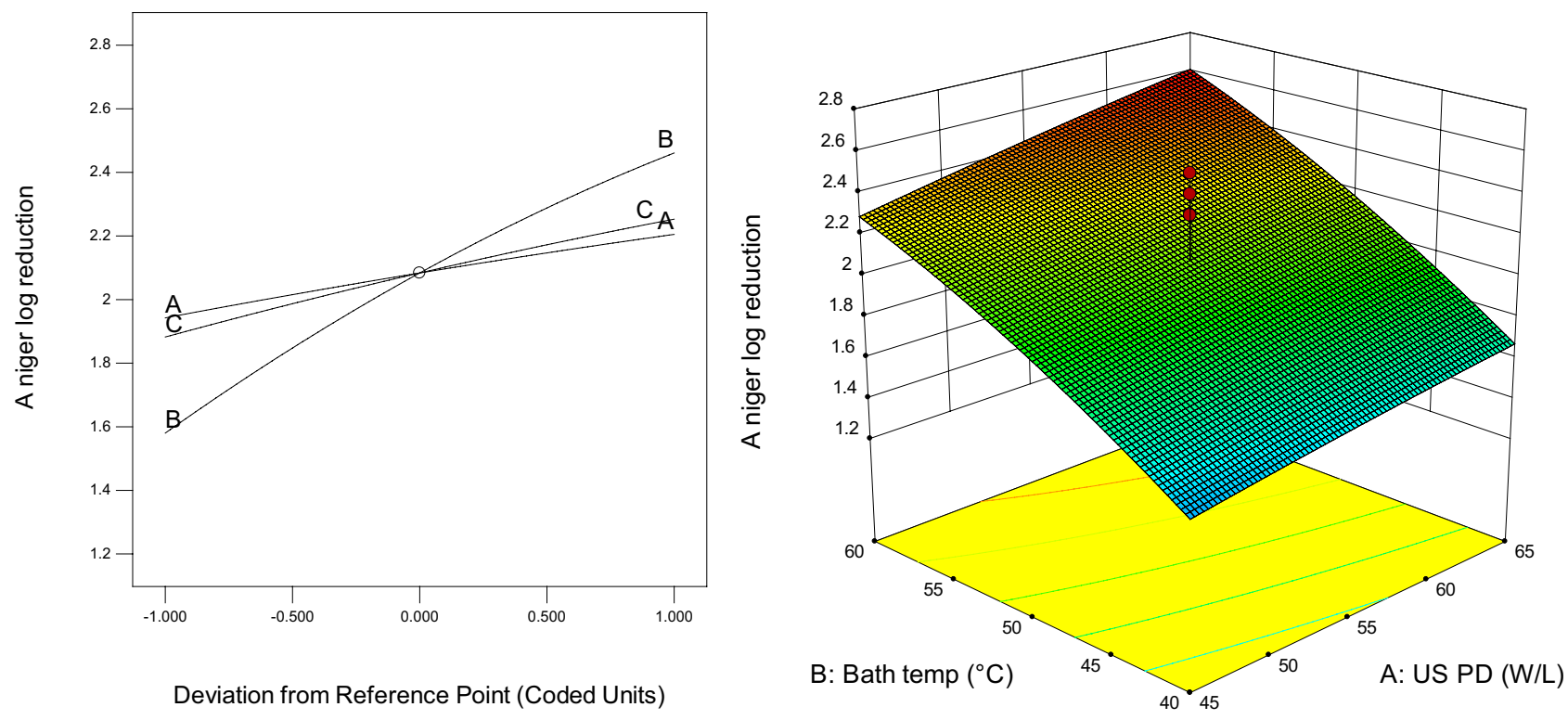

Fig. 4 Effect of bath temperature, US PD, and duration on log reduction of Aspergillus niger (A niger) 
Table 3 Experimental condition for the three variables, five-level central composite design (CCD) matrix with responses for microwave pretreatment

\begin{tabular}{|c|c|c|c|c|c|c|}
\hline Run & MW PD $\left(\mathrm{Wg}^{-1}\right)$ & Duration (s) & FT $\left({ }^{\circ} \mathrm{C}\right)$ & $\begin{array}{l}\% \text { POD inactivation } \\
(\text { mean } \pm \mathrm{SD})\end{array}$ & $\begin{array}{l}\% \text { PPO inactivation } \\
(\text { mean } \pm \mathrm{SD})\end{array}$ & $\begin{array}{l}\text { Aspergillus niger } \\
\text { log reduction } \\
(\text { mean } \pm S D)\end{array}$ \\
\hline 1 & 2.50 & 110 & $65 \pm 3$ & $48.60 \pm 1.22$ & $49.55 \pm 1.32$ & $1.00 \pm 0.06$ \\
\hline 2 & 0.38 & 110 & $33 \pm 4$ & $12.05 \pm 0.38$ & $24.07 \pm 0.09$ & $0.40 \pm 0.09$ \\
\hline 3 & 2.50 & 110 & $60 \pm 2$ & $53.12 \pm 1.06$ & $52.01 \pm 1.02$ & $1.20 \pm 0.10$ \\
\hline 4 & 4.00 & 40 & $54 \pm 4$ & $65.69 \pm 0.80$ & $72.07 \pm 0.80$ & $1.80 \pm 0.27$ \\
\hline 5 & 2.50 & 110 & $62 \pm 3$ & $55.40 \pm 0.64$ & $55.31 \pm 0.19$ & $1.20 \pm 0.02$ \\
\hline 6 & 1.00 & 180 & $48 \pm 2$ & $36.55 \pm 0.74$ & $43.28 \pm 0.95$ & $1.60 \pm 0.08$ \\
\hline 7 & 2.50 & 110 & $68 \pm 4$ & $50.89 \pm 1.30$ & $58.61 \pm 0.34$ & $1.50 \pm 0.03$ \\
\hline 8 & 4.00 & 180 & $83 \pm 3$ & $84.39 \pm 0.32$ & $89.21 \pm 0.49$ & $2.30 \pm 0.12$ \\
\hline 9 & 4.62 & 110 & $78 \pm 5$ & $87.95 \pm 0.45$ & $75.72 \pm 0.65$ & $1.90 \pm 0.07$ \\
\hline 10 & 2.50 & 110 & $58 \pm 3$ & $62.01 \pm 2.26$ & $63.20 \pm 0.59$ & $1.50 \pm 0.03$ \\
\hline 11 & 1.00 & 40 & $34 \pm 4$ & $19.88 \pm 1.26$ & $29.04 \pm 1.01$ & $0.50 \pm 0.11$ \\
\hline 12 & 2.50 & 209 & $80 \pm 3$ & $85.71 \pm 0.60$ & $81.83 \pm 0.32$ & $1.90 \pm 0.07$ \\
\hline 13 & 2.50 & 11 & $34 \pm 2$ & $17.74 \pm 0.84$ & $22.04 \pm 1.78$ & $0.60 \pm 0.11$ \\
\hline
\end{tabular}

The SD is the standard deviation which was calculated from three replications

desirability values. The responses at optimum condition were $71.24{ }^{\circ} \mathrm{C}$ final water bath temperature, $80.87 \%$ POD inactivation, $93.80 \%$ PPO inactivation, and $2.60 \mathrm{log}$ reduction in Aspergillus niger.

\section{Effect of Microwave Power Density and Duration on POD and PPO Activity and Aspergillus Niger Inactivation}

After MW pretreatment, the moisture content of garlic bulbs

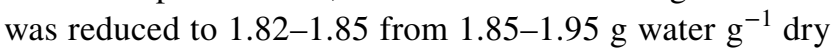

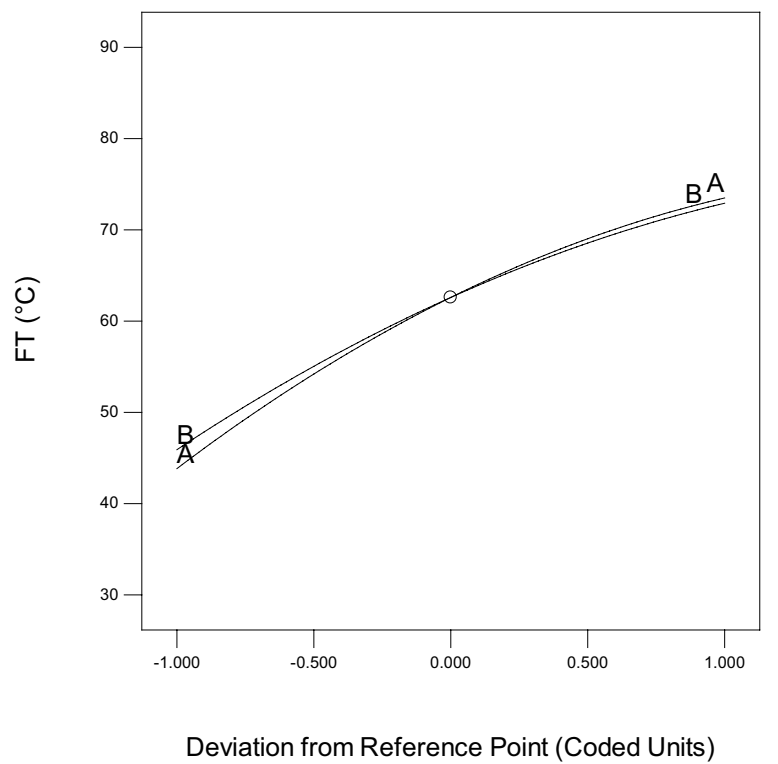

Fig. 5 Effect of MW PD and duration on final product temperature matter. Microwave power density and treatment time significantly reduced enzyme activity and Aspergillus niger as well as increased final product temperature. The responses collected in the MW treatment are given in Table 3. The perturbation analysis and surface plots (Figs. 5, 6, 7, 8 and 9) show the effect of independent variables on the responses. POD activity reduction was in the range 12.05 to $87.95 \%$, and PPO activity reduction was in the range 22.04 to $81.21 \%$ when microwave power density varied from 1 to $4 \mathrm{Wg}^{-1}$ and treatment time varied from 40 to $180 \mathrm{~s}$. Fante and Noreña (2012) observed a non-significant difference in POD activity

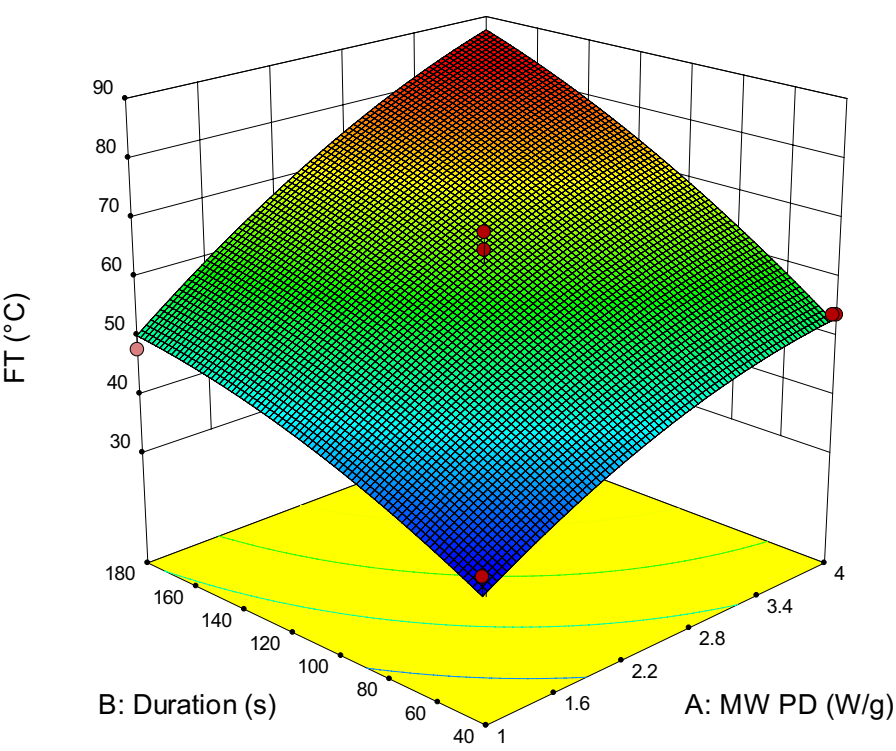




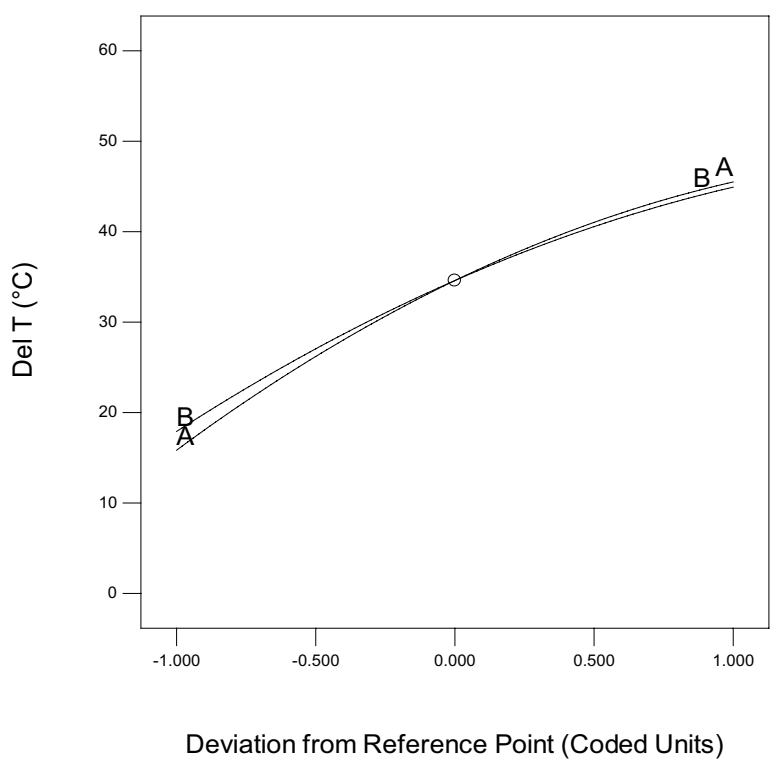

Fig. 6 Effect of MW PD and duration on temperature difference (Del T)

of garlic after 4 min and 6 min of blanching in steam at $90{ }^{\circ} \mathrm{C}$ and water at $80{ }^{\circ} \mathrm{C}$, respectively, and for PPO, no significant difference was observed even after $8 \mathrm{~min}$ of treatment at $80{ }^{\circ} \mathrm{C}$. During our study, microwave pretreatment showed nearly $80 \%$ reductions in PPO and POD activity within 3 min compared to hot water blanching, as reported in the literature. Fante and Noreña (2012) reported POD and PPO activity loss by $94.47 \%$ and $91.39 \%$, respectively, after 10 min of water blanching at $90{ }^{\circ} \mathrm{C}$.

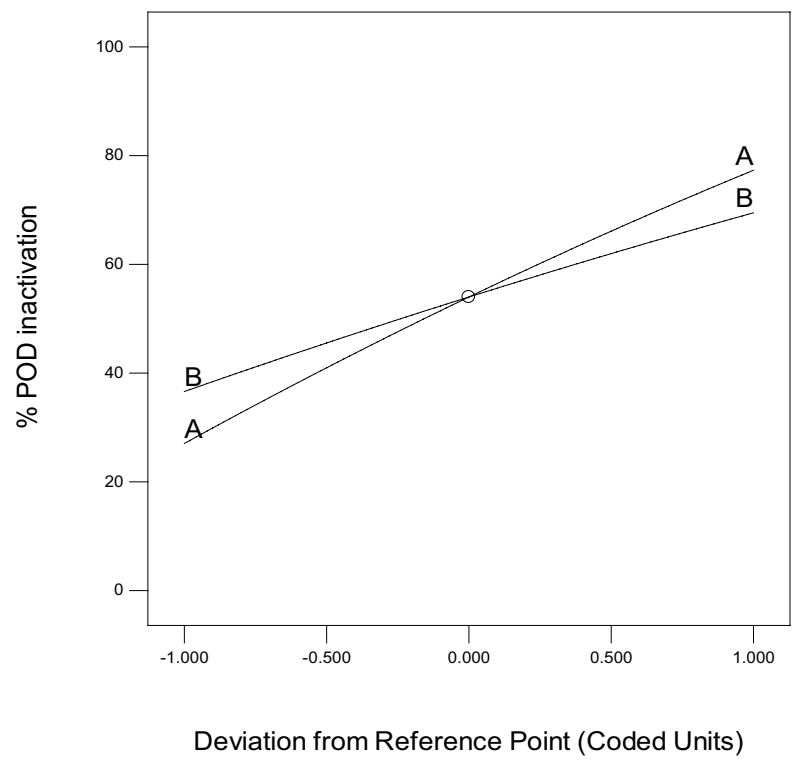

Fig. 7 Effect of MW PD and duration on \% POD inactivation

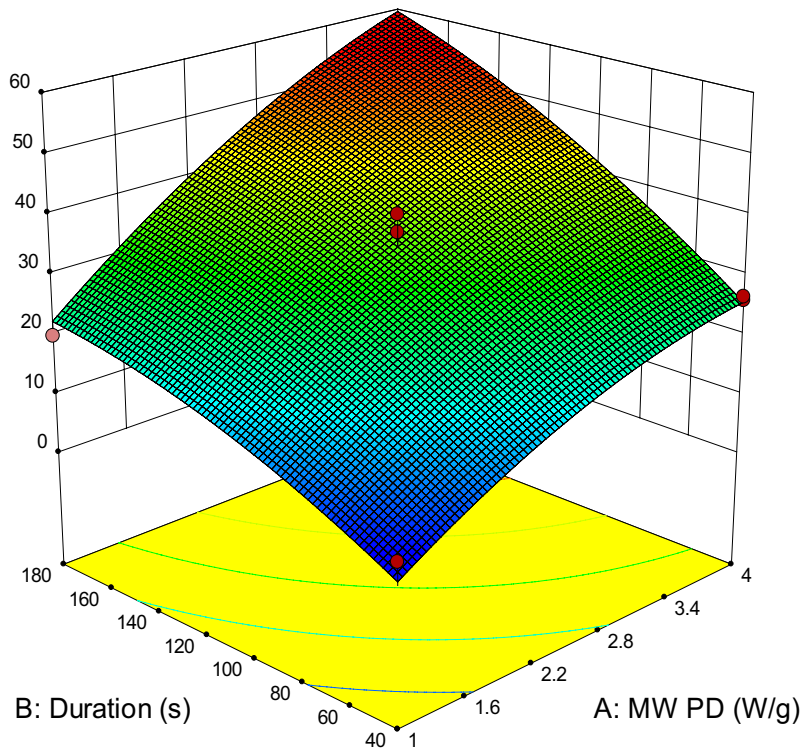

An inactivation effect of microwave heating on POD and PPO might be due to the change in conformation of the enzyme protein at high temperatures $\left(55^{\circ}-82^{\circ} \mathrm{C}\right)$. The reduction in enzyme activity in a short time ( 40 to $180 \mathrm{~s}$ ) also might be due to the disruption of hydrogen bonds, disulphide, and other weaker bonds, thus facilitating protein unfolding and changing its secondary and tertiary structures by microwaves heating. Enzyme inactivation depends on the extent and location of these structural changes (de

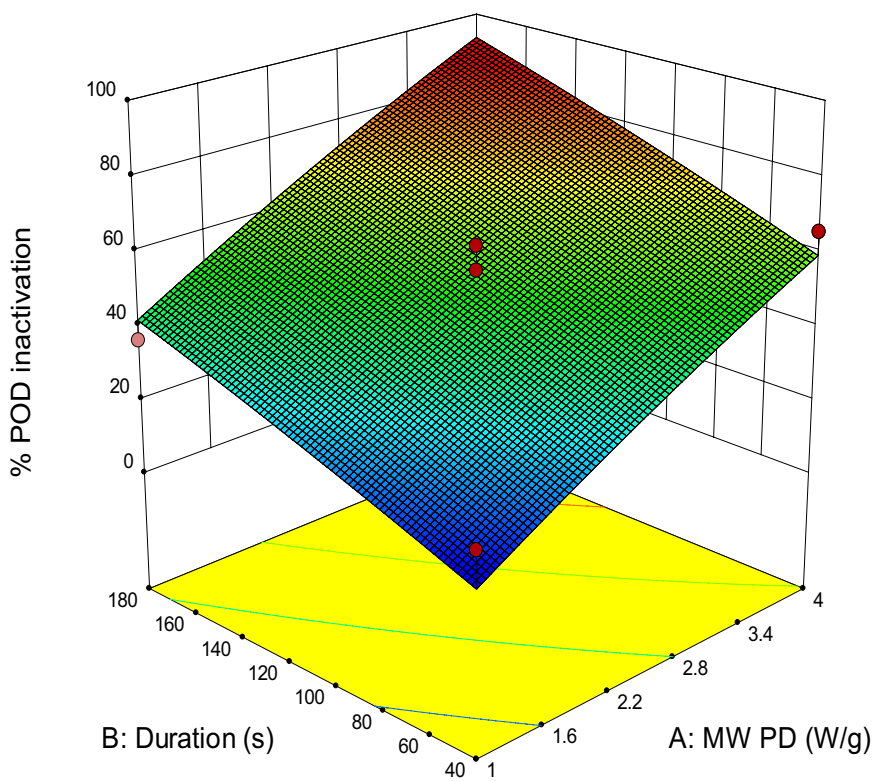




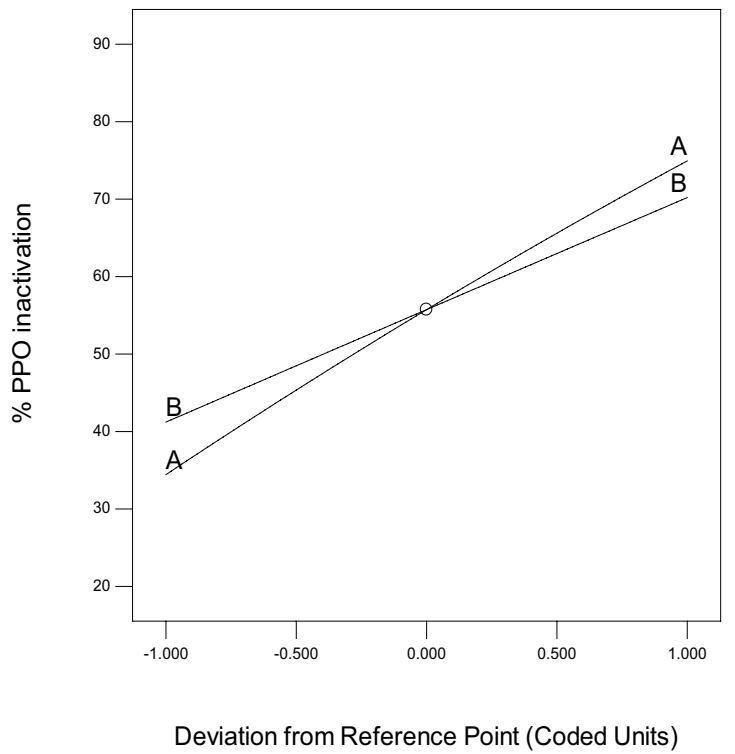

Fig. 8 Effect of MW PD and duration on \% PPO inactivation

Barcelos Costa et al., 2020). Some studies also suggest the enzyme inactivation because of conformational changes in polar groups due to rotational and translational motion by the oscillating electromagnetic field (Han et al., 2018). The degree of POD inactivation varied differently during the experimental range might be due to different heat resistances of isoenzymes. In POD, two isozymes have already been reported with different thermostabilities, resulting in POD inactivation at biphasic stages. The inactivation temperature of the two isoenzymes is related to the donor matrix provided (Yao et al., 2020).

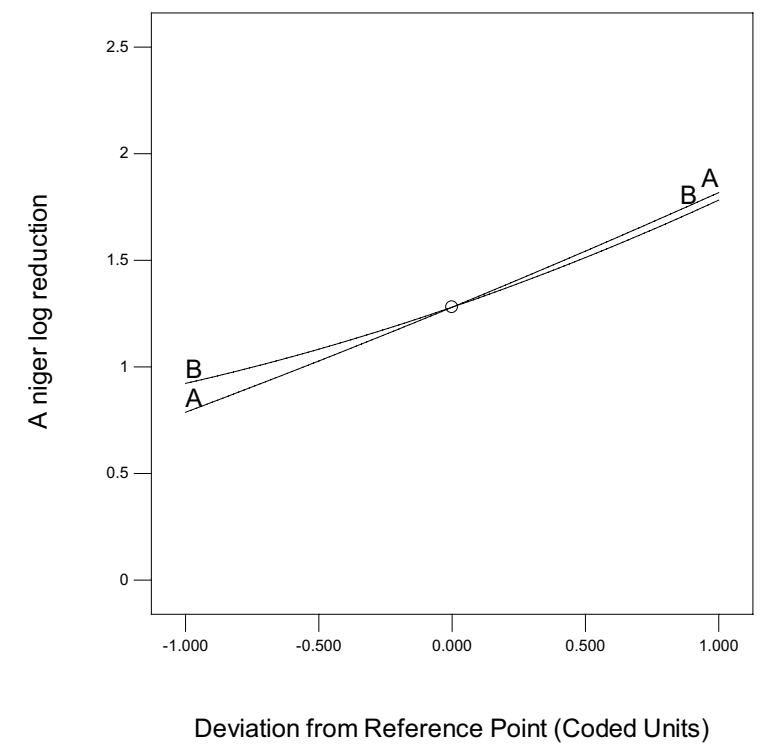

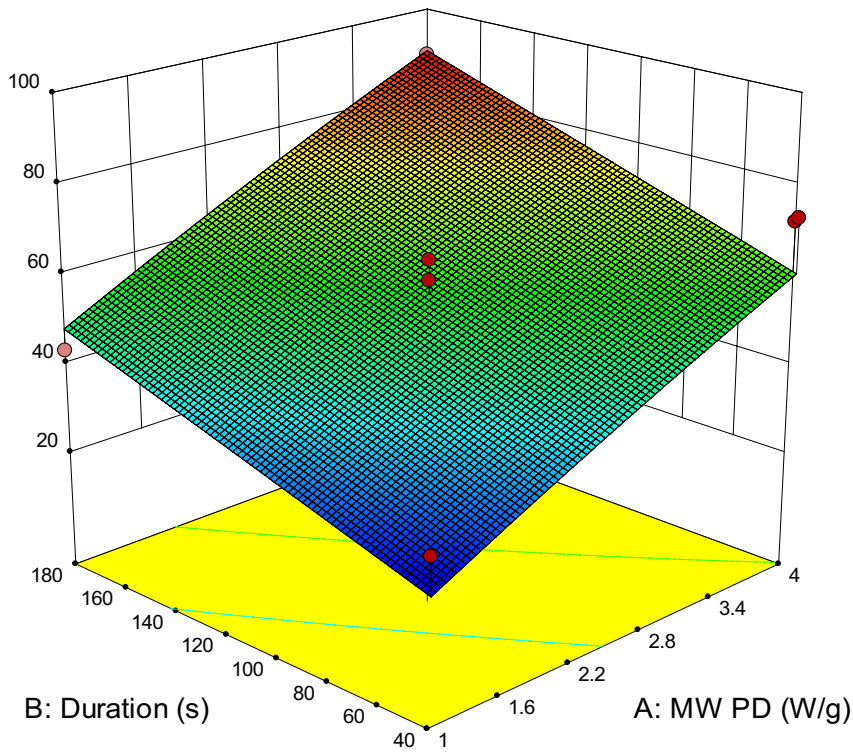

The average temperature of garlic varied from $28^{\circ}$ to $88^{\circ} \mathrm{C}$ during the microwave heating process. Aspergillus niger $\log$ reduction was found to be in the range 0.4-2.6, and enzymes inactivation was between 25 and $80 \%$ in the experimental range. Higher enzyme and microbial inactivation occurred at $4 \mathrm{Wg}^{-1}$ power density in $180 \mathrm{~s}$ as the rise in temperature was achieved from $77^{\circ}$ to $84^{\circ} \mathrm{C}$. Approximately $2 \log$ reduction in standard plate count in pear snack was reported due to microwave processing (Devi et al., 2021). At different processing conditions, POD and PPO showed varying thermal resistance to

Fig. 9 Effect of MWPD and duration on log reduction of Aspergillus niger (A niger)

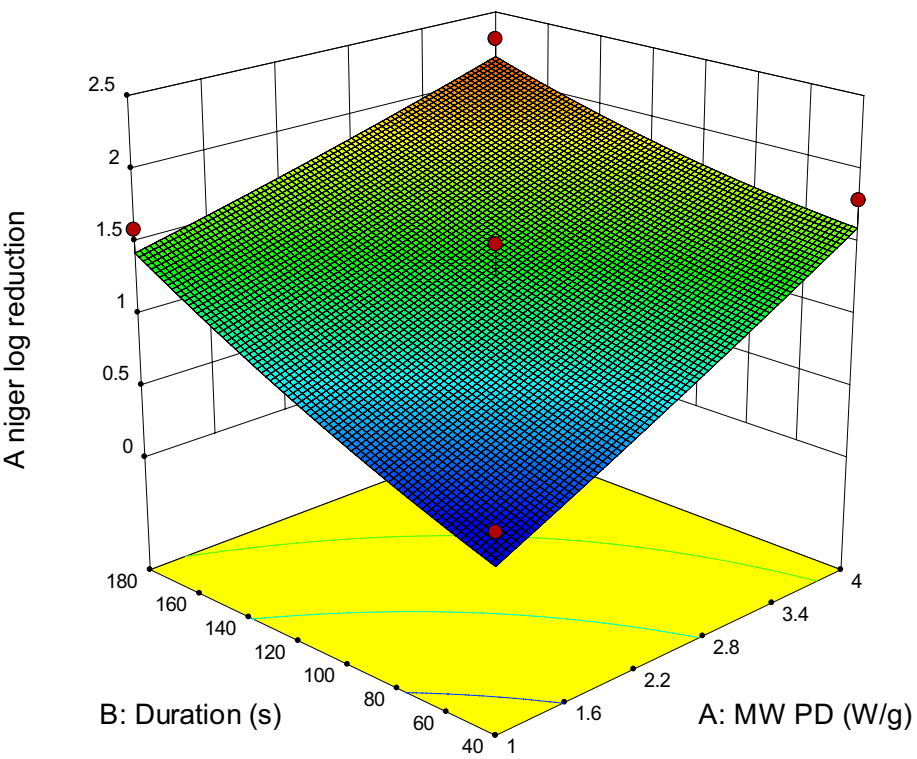


microwave treatment. It has been reported that the treatments resulting in low final product temperature (within $68{ }^{\circ} \mathrm{C}$ ) showed higher PPO inactivation than POD. But in most of the cases, the treatment resulting in higher final product temperature had higher inactivation of POD than PPO. Some studies have reported PPO to be more thermally resistant than POD during microwave treatment of coconut water and strawberry puree above $77{ }^{\circ} \mathrm{C}$ (Marszałek et al., 2015; Salazar-González et al., 2012). Marszałek et al. (2015) found that only thermal pasteurization led to the effective inactivation of both PPO and POD enzymes in strawberry puree, whereas microwave treatment could inactivate $80 \%$ of PPO activity at $90{ }^{\circ} \mathrm{C}$ and $120{ }^{\circ} \mathrm{C}$, regardless of the heating time. Microwaves at $80^{\circ} \mathrm{C}$ operating temperature were less effective in PPO inactivation. They also found out POD was less resistant to microwave heating than PPO.

The ANOVA for POD, PPO, and Aspergillus niger inactivation of garlic is given in Table 4 . All the independent variables significantly $(p<0.01)$ affected the enzyme and Aspergillus niger inactivation. The quadratic model Eqs. (12) and (13) was fitted well to the enzyme inactivation data $(p<0.01)$ with a non-significant lack of fit. The $\mathrm{R}^{2}$ of the models for POD, PPO, and Aspergillus niger inactivation was $0.90,0.92$, and 0.89 , respectively. The correlation between final product temperature $\left(T_{p}\right), \mathrm{POD}, \mathrm{PPO}$, and Aspergillus niger inactivation and independent parameters is given below by eliminating non-significant terms:

$T_{p}=7.737+14.680 P_{m}+0.246 t_{m}$

$\%$ POD inactivation $=-19.740+20.241 P_{m}+0.265 t_{m}$

$\%$ PPO inactivation $=-1.876+15.072 P_{m}+0.191 t_{m}$

Aspergillus niger reduction $=-0.405+0.451 P_{m}+6.456 \times 10^{-3} t_{m}$

where $P_{m}$ and $t_{m}$ refer to microwave power density and treatment duration, respectively. Optimization of the microwave pretreatment process.

Response surfaces were generated from the developed regressions for all responses, and the numerical optimization was carried out by using the equations and desirability function. For this purpose, microwave power density was set below or equal to $3 \mathrm{Wg}^{-1}$ and duration (20-180 s) as that of the experimental range with a maximum possible inactivation of POD and PPO enzymes and Aspergillus niger. The optimization criteria for microwave power density were kept below $4 \mathrm{Wg}^{-1}$ as garlic tissue softening was observed at 4 and $4.62 \mathrm{Wg}^{-1}$ power density with 180 and $110 \mathrm{~s} \mathrm{dura-}$ tion, respectively. Like US, the L, a, b colour change in MW process was found to be non-significant. Therefore, in the MW optimization process also the change in colour values was not used. The optimum conditions for microwave pretreatment for garlic were found to be $3 \mathrm{Wg}^{-1}$ microwave power density for 180 s duration with 0.826 desirability value. The responses at optimum condition were $76.68^{\circ} \mathrm{C}$ final average product temperature, $77.84 \%$ POD inactivation, $77.04 \%$ PPO inactivation, and 1.90 log reduction in Aspergillus niger.

\section{Ultrasound and MW Heating Characteristics}

The rise in temperature due to ultrasound and microwave treatment is shown in Figs. 10 and 11. The temperature of the ultrasound water bath at three power levels $(45,55,65$ $\mathrm{WL}^{-1}$ ) was recorded for $20 \mathrm{~min}$ at an interval of $2 \mathrm{~min}$. The temperature of the water bath was reached $39^{\circ}, 40^{\circ}, 42^{\circ} \mathrm{C}$ at the end of the treatments at 45,55 and $65 \mathrm{WL}^{-1}$ ultrasonic power density, respectively. The heating rates were found to be $0.70^{\circ}, 0.75^{\circ}, 0.85^{\circ} \mathrm{C} \mathrm{min}{ }^{-1}$ at 45,55 , and 65 $\mathrm{WL}^{-1}$, respectively. During the initial stage of ultrasonication pretreatment, a nearly similar rise in temperature was observed at all ultrasound power density levels. Till $8 \mathrm{~min}$ of ultrasonication, the temperature of the water bath at all the ultrasound power density levels showed nearly similar temperature rise, but after $8 \mathrm{~min}$, temperature rise happened according to the ultrasound power levels. Also, the average of three higher temperatures of garlic was recorded as $53.6^{\circ}$, $74.3^{\circ}, 78.4^{\circ} \mathrm{C}$ at $1,2.5$, and $4 \mathrm{Wg}^{-1}$ power density levels, respectively. The heating rates were found to be $11.4^{\circ}, 20.4^{\circ}$, and $22.2^{\circ} \mathrm{C} \mathrm{min}^{-1}$ at $1,2.5$, and $4 \mathrm{Wg}^{-1}$ power densities, respectively. The sharp temperature shoot was observed in garlic due to high power microwave pretreatment in a short duration. This might be due to the high dielectric loss factor at the garlic's relatively higher initial moisture content.

\section{Specific Energy Consumption}

Specific energy consumption during the ultrasonication process at $45,55,65 \mathrm{WL}^{-1}$ for 20 min was $0.015,0.018$, and 0.022 Watt-h $\mathrm{g}^{-1}$, respectively. During MW heating, specific energy consumption at $1,2.5$, and $4 \mathrm{Wg}^{-1}$ power densities for 2 min was $0.033,0.083$, and 0.133 Watt-h $\mathrm{g}^{-1}$, respectively. During ultrasonication, the specific energy consumption at optimized $\left(65 \mathrm{WL}^{-1}\right.$ at $57.15^{\circ} \mathrm{C}$ for $\left.39.99 \mathrm{~min}\right)$ pretreatment was 0.084 Watt-h $\mathrm{g}^{-1}$. The specific energy consumption was calculated by adding the specific energy consumption to raise the temperature from ambient to $57.15{ }^{\circ} \mathrm{C}$ with specific energy consumption due to the treatment. During MW optimized treatment $\left(3 \mathrm{Wg}^{-1}\right.$ for $\left.180 \mathrm{~s}\right)$, the specific energy consumption was 0.15 Watt-h g ${ }^{-1}$. 
Table 4 ANOVA table for $\Delta \mathrm{T}$, POD, PPO, and Aspergillus niger inactivation for microwave pretreatment

\begin{tabular}{|c|c|c|c|c|c|c|}
\hline Source & $\begin{array}{l}\text { Sum of } \\
\text { Squares }\end{array}$ & df & $\begin{array}{l}\text { Mean } \\
\text { Square }\end{array}$ & $\begin{array}{l}\text { F } \\
\text { Value }\end{array}$ & $\begin{array}{l}\text { p-value } \\
\text { Prob }>\text { F }\end{array}$ & \\
\hline \multicolumn{7}{|l|}{$\Delta \mathrm{T}$} \\
\hline Model & 3432.48 & 5 & 686.5 & 34.87 & $<0.0001$ & significant \\
\hline A-MW PD & 1759.42 & 1 & 1759.42 & 89.36 & $<0.0001$ & \\
\hline B-Duration & 1459.45 & 1 & 1459.45 & 74.12 & $<0.0001$ & \\
\hline $\mathrm{AB}$ & 56.25 & 1 & 56.25 & 2.86 & 0.1348 & \\
\hline $\mathrm{A}^{2}$ & 107.17 & 1 & 107.17 & 5.44 & 0.0524 & \\
\hline $\mathrm{B}^{2}$ & 70.13 & 1 & 70.13 & 3.56 & 0.1011 & \\
\hline Residual & 137.83 & 7 & 19.69 & & & \\
\hline Lack of Fit & 74.63 & 3 & 24.88 & 1.57 & 0.3275 & not significant \\
\hline Pure Error & 63.2 & 4 & 15.8 & & & \\
\hline Cor Total & 3570.31 & 12 & & & & \\
\hline $\mathrm{R}^{2}$ & 0.96 & & & & & \\
\hline Adj $R^{2}$ & 0.93 & & & & & \\
\hline Pred $R^{2}$ & 0.82 & & & & & \\
\hline C.V. $\%$ & 14.68 & & & & & \\
\hline $\mathrm{SD}$ & 4.44 & & & & & \\
\hline \multicolumn{7}{|c|}{$\%$ POD inactivation } \\
\hline Model & 7238.33 & 5 & 1447.67 & 17.13 & 0.0008 & significant \\
\hline$A-M W P D$ & 5049.56 & 1 & 5049.56 & 59.74 & 0.0001 & \\
\hline B-Duration & 2161.34 & 1 & 2161.34 & 25.57 & 0.0015 & \\
\hline$A B$ & 1.03 & 1 & 1.03 & 0.012 & 0.9152 & \\
\hline$A^{2}$ & 22.81 & 1 & 22.81 & 0.27 & 0.6195 & \\
\hline$B^{2}$ & 6.26 & 1 & 6.26 & 0.074 & 0.7934 & \\
\hline Residual & 591.7 & 7 & 84.53 & & & \\
\hline Lack of Fit & 485.98 & 3 & 161.99 & 6.13 & 0.0562 & not significant \\
\hline Pure Error & 105.73 & 4 & 26.43 & & & \\
\hline Cor Total & 7830.03 & 12 & & & & \\
\hline $\mathrm{R}^{2}$ & 0.92 & & & & & \\
\hline Adj $R^{2}$ & 0.87 & & & & & \\
\hline Pred $\mathrm{R}^{2}$ & 0.54 & & & & & \\
\hline C.V. $\%$ & 17.58 & & & & & \\
\hline $\mathrm{SD}$ & 9.19 & & & & & \\
\hline \multicolumn{7}{|c|}{$\%$ PPO inactivation } \\
\hline Model & 4970.65 & 5 & 994.13 & 11.34 & 0.003 & significant \\
\hline A-MW PD & 3280.67 & 1 & 3280.67 & 37.43 & 0.0005 & \\
\hline B-Duration & 1680.14 & 1 & 1680.14 & 19.17 & 0.0032 & \\
\hline $\mathrm{AB}$ & 2.1 & 1 & 2.1 & 0.024 & 0.8813 & \\
\hline $\mathrm{A}^{2}$ & 7.66 & 1 & 7.66 & 0.087 & 0.7761 & \\
\hline $\mathrm{B}^{2}$ & $5.95 \times 10^{-3}$ & 1 & $5.952 \times 10^{-3}$ & $6.79 \times 10^{-3}$ & 0.9937 & \\
\hline Residual & 613.48 & 7 & 87.64 & & & \\
\hline Lack of Fit & 497.17 & 3 & 165.72 & 5.7 & 0.063 & not significant \\
\hline Pure Error & 116.3 & 4 & 29.08 & & & \\
\hline Cor Total & 5584.13 & 12 & & & & \\
\hline $\mathrm{R}^{2}$ & 0.89 & & & & & \\
\hline Adj $R^{2}$ & 0.81 & & & & & \\
\hline Pred $\mathrm{R}^{2}$ & 0.33 & & & & & \\
\hline C.V. $\%$ & 17 & & & & & \\
\hline $\mathrm{SD}$ & 9.36 & & & & & \\
\hline \multicolumn{7}{|c|}{ Aspergillus niger log reduction } \\
\hline Model & 3.73 & 5 & 0.75 & 11.81 & 0.0026 & significant \\
\hline
\end{tabular}


Table 4 (continued)

\begin{tabular}{|c|c|c|c|c|c|c|}
\hline Source & $\begin{array}{l}\text { Sum of } \\
\text { Squares }\end{array}$ & df & $\begin{array}{l}\text { Mean } \\
\text { Square }\end{array}$ & $\begin{array}{l}\text { F } \\
\text { Value }\end{array}$ & $\begin{array}{l}\text { p-value } \\
\text { Prob }>\text { F }\end{array}$ & \\
\hline A-MW PD & 2.12 & 1 & 2.12 & 33.63 & 0.0007 & \\
\hline B-Duration & 1.48 & 1 & 1.48 & 23.41 & 0.0019 & \\
\hline $\mathrm{AB}$ & 0.09 & 1 & 0.09 & 1.43 & 0.2714 & \\
\hline$A^{2}$ & $3.522 \times 10^{-3}$ & 1 & $3.522 \times 10^{-3}$ & 0.056 & 0.8201 & \\
\hline $\mathrm{B}^{2}$ & 0.037 & 1 & 0.037 & 0.58 & 0.4715 & \\
\hline Residual & 0.44 & 7 & 0.063 & & & \\
\hline Lack of Fit & 0.25 & 3 & 0.085 & 1.8 & 0.2865 & not significant \\
\hline Pure Error & 0.19 & 4 & 0.047 & & & \\
\hline Cor Total & 4.17 & 12 & & & & \\
\hline $\mathrm{R}^{2}$ & 0.89 & & & & & \\
\hline Adj $R^{2}$ & 0.82 & & & & & \\
\hline Pred $R^{2}$ & 0.5 & & & & & \\
\hline C.V. $\%$ & 18.77 & & & & & \\
\hline SD & 0.25 & & & & & \\
\hline
\end{tabular}

Two-Stage Sequential Ultrasound Followed by Microwave Pretreatment for Blanching-Cum-Black Mould Inactivation

In blanching treatment, a 90\% reduction in POD activity is usually considered as the endpoint of blanching. From research studies and preliminary experiments, it was observed that individually ultrasound or microwave could not inactivate both POD and PPO above 90\% (Costa et al., 2013; Marszałek et al., 2015). Several preliminary studies were carried out, and it was observed that high power microwave heating alone resulted in nonuniform heating of garlic bulbs. The centre portion of garlic bulbs becomes black due to overheating and burning. Due to microwave heating alone, a high fluctuation in garlic bulb temperature $\left(42-80^{\circ} \mathrm{C}\right)$ was observed. Therefore, the water ultrasonication blanching

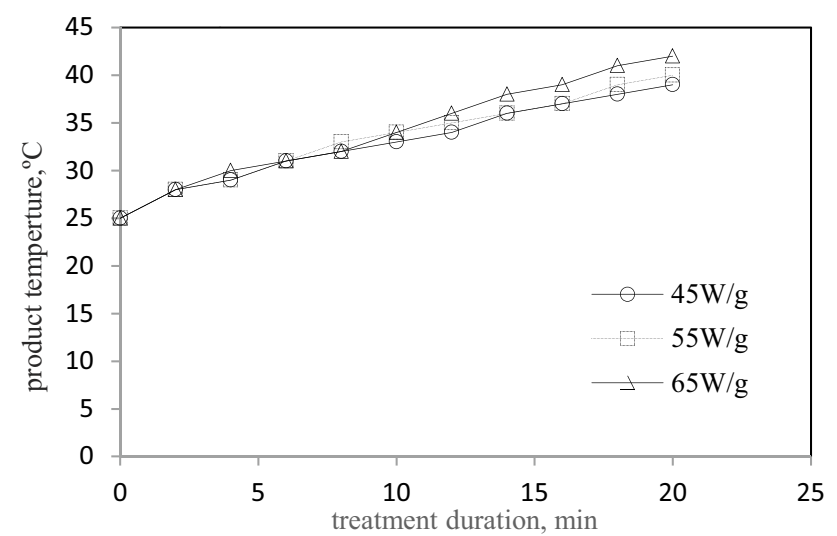

Fig. 10 Product temperature rise at different levels of US power densities pretreatment was applied before microwave heating. It was observed that the ultrasound-treated sample after microwave heating retained its firmness and texture as well as the nonuniform heating issue in MW was nearly resolved. The SEM images (Fig. 12) also confirmed the enhanced porous structure in garlic due to ultrasound, whereas microwave alone had resulted in the distorted pore structure. This shows the increase in efficiency of microwave treatment due to ultrasonication. Also, another preliminary study on microwave treatment followed by the US was carried out, but it resulted in the softening and bursting of the garlic bulb. Therefore, the ultrasonication followed by microwave was selected as the appropriate pretreatment. So the garlic bulbs were treated with ultrasound followed by microwaves to get the required enzyme inactivation. After the ultrasonication treatment, the garlic bulbs were immediately taken out and blotted with

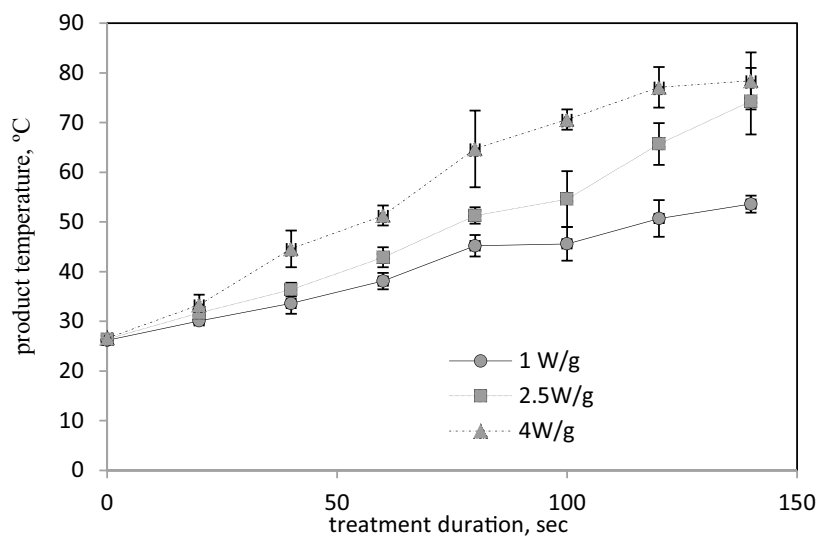

Fig. 11 Product temperature rise at different levels of MW power densities 

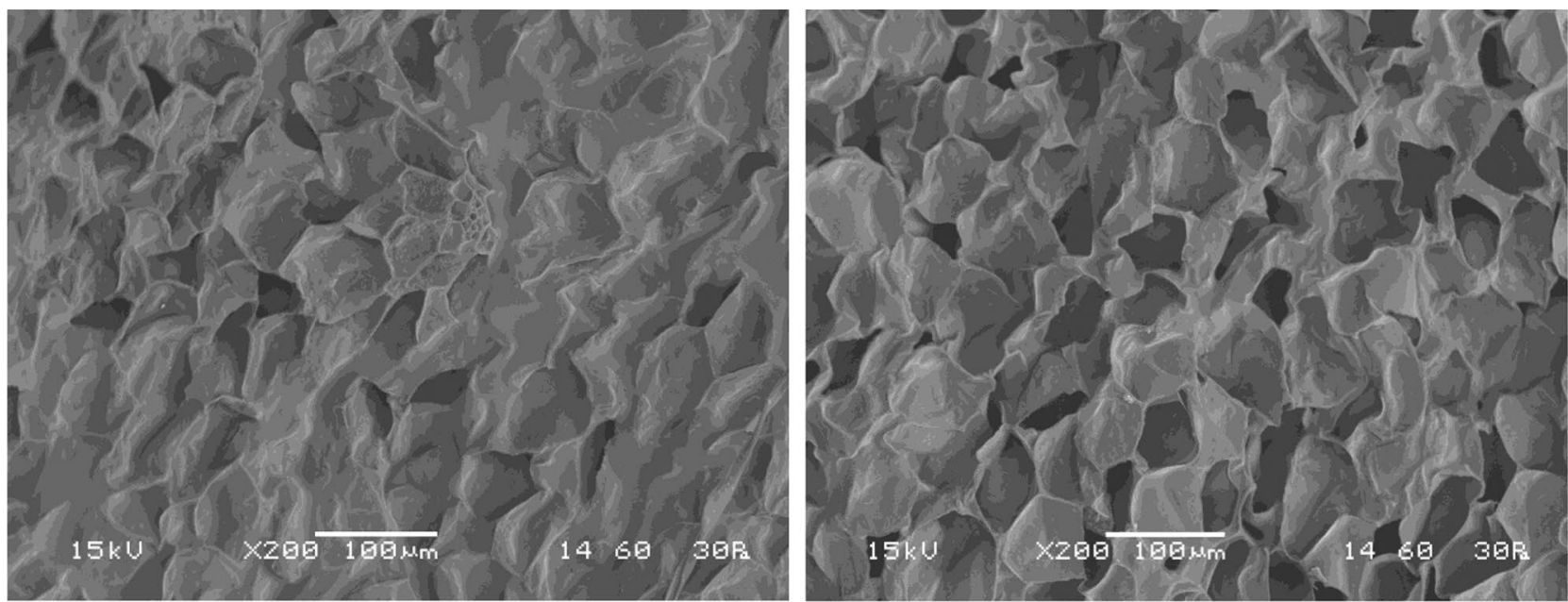

a. US treated closed pore section

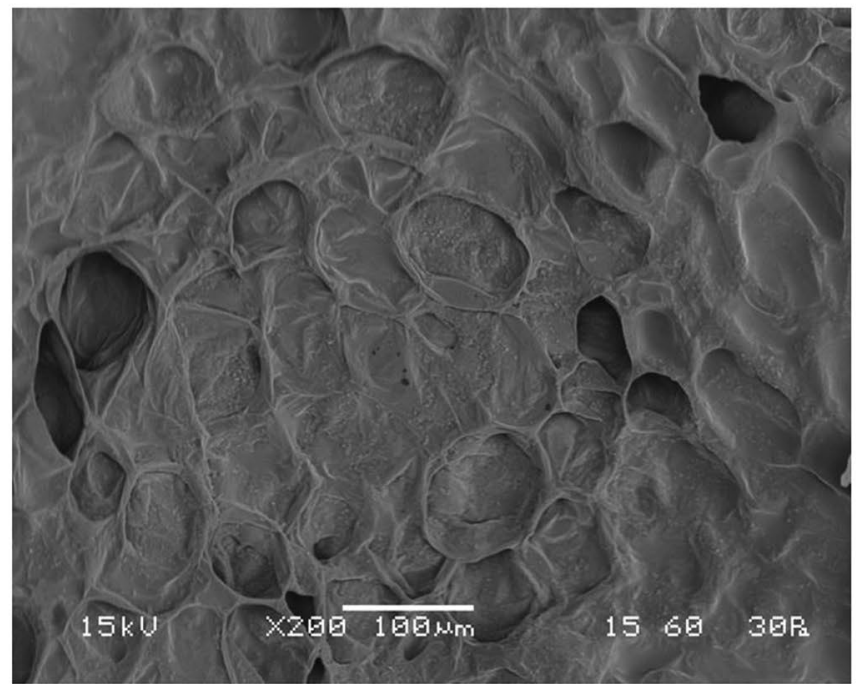

c. MW treated closed pore section

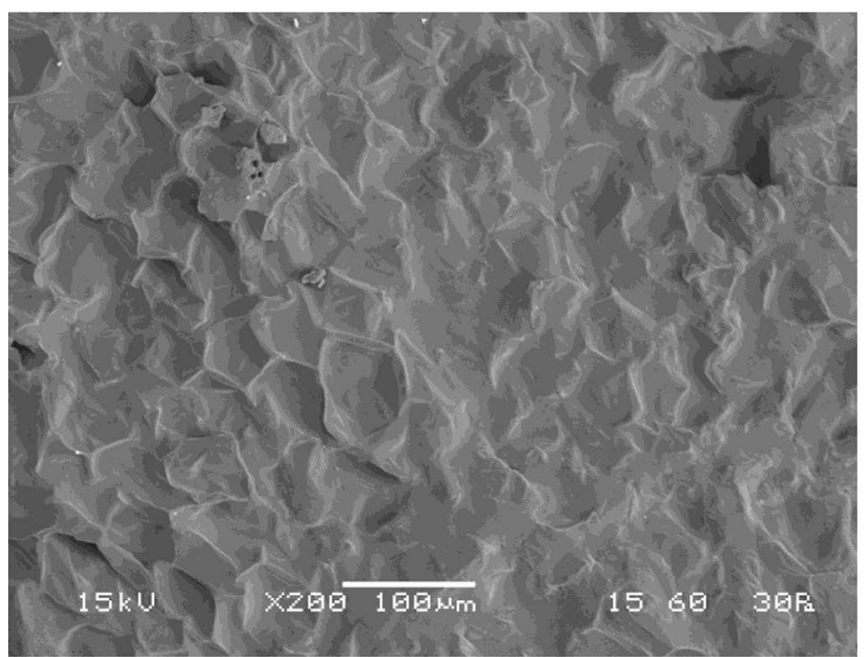

e. Raw closed pore section

Fig. 12 SEM images of US- and MW-treated and untreated garlic section

\section{b. US treated open pore section}

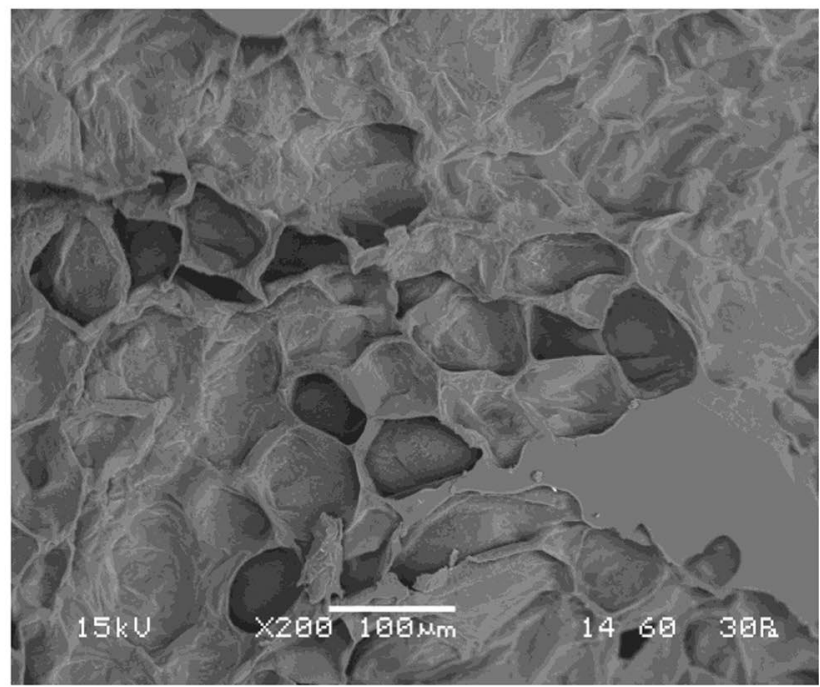

d. MW treated open pore section

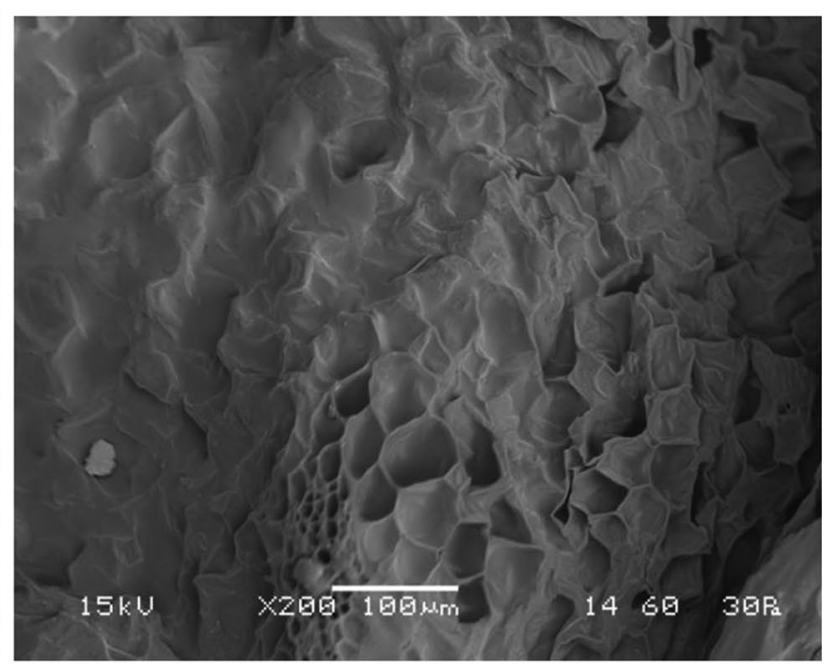

f. Raw open pore section 
tissue paper to remove surface moisture and subjected to MW treatment. As the specific energy consumption estimate was higher during the microwave pretreatment alone, it was required to study the two-stage combination of the optimized ultrasonication $\left(58.43 \mathrm{WL}^{-1}\right.$ ultrasound power density, initial bath temperature of $60^{\circ} \mathrm{C}$ and $40 \mathrm{~min}$ ) and the optimized microwave power density $\left(3 \mathrm{Wg}^{-1}\right)$ for 60,120 , and $180 \mathrm{~s}$ followed by the investigation of POD, PPO, and Aspergillus niger. For $58.43 \mathrm{WL}^{-1}$ US power density, $100 \mathrm{~g} \mathrm{(4-5}$ numbers) of garlic bulbs was treated. Then, out of $100 \mathrm{~g}$ of US-treated garlic bulbs, approximately $50 \%$ garlic bulbs (50.3 g, 2-3 numbers) were used in MW pretreatment at 3 $\mathrm{Wg}^{-1} \mathrm{MW}$ power density. All the experiments were carried out in three replicates. It was observed that US + MW-60 s, US + MW-120 s, US + MW-180 s resulted in $87.66 \pm 0.60$, $90.37 \pm 0.32$, and $87.09 \pm 0.95 \%$ POD inactivation and the final product temperature was $80^{\circ}, 83^{\circ}$, and $84^{\circ} \mathrm{C}$ at the end of the corresponding experiments, respectively. Similarly, US + MW-60 s, US + MW-120 s, US + MW-180 s resulted in $90.02 \pm 0.49,92.38 \pm 0.30$, and $90.5 \pm 0.09 \%$ of PPO inactivation and $2.60 \pm 0.12,2.62 \pm 0.28$, and $2.65 \pm 0.06 \mathrm{log}$ reduction in Aspergillus niger, respectively. Ochratoxins A (OTA) is one of the most abundant food-contaminating mycotoxins and a secondary metabolite of toxigenic species of Aspergillus and Penicillium moulds, like Aspergillus niger or $P$. verrucosum (Riba et al., 2008). European Union countries have imposed limits on OTA content in coffee and foods, in some cases as stringent as $5 \mathrm{ng} / \mathrm{g}$ (Bayman et al., 2002). Durek et al. (2018) reported that OTA production by Aspergillus niger (inoculation with a mycelium suspension) of $5.32 \pm 0.02 \log$ CFU/g and $2.32 \pm 0.58 \log$ CFU/g was $0.16 \mathrm{ng} / \mathrm{g}$ and $0.9 \mathrm{ng} / \mathrm{g}$, respectively. They found that in barley inoculated with spore suspension, Aspergillus niger of $4.6 \log \mathrm{CFU} / \mathrm{g}$ and $2.4 \log \mathrm{CFU} / \mathrm{g}$ produced OTA of $0.1 \mathrm{ng} / \mathrm{g}$ and $0.06 \mathrm{ng} / \mathrm{g}$, respectively. Also, the International Commission on Microbiological Specifications for Foods (ICMSF) set up a maximum limit of $10^{4} \mathrm{CFU}$ of moulds and yeasts/g of spices (González et al., 2017). Therefore, the final selected US treatment $\left(58.43 \mathrm{WL}^{-1}\right.$ ultrasound power density, initial bath temperature of $60^{\circ} \mathrm{C}$ and $40 \mathrm{~min}$ ) followed by $3 \mathrm{Wg}^{-1} \mathrm{MW}$ heating for $120 \mathrm{~s}$ which resulted in higher enzyme inactivation with safe Aspergillus niger count $(1.74-1.85 \log \mathrm{CFU} / \mathrm{g})$ in the garlic can be considered as a best pretreatment prior to drying.

\section{Microstructural Changes in Ultrasound and Microwave Pre-Treated Garlic Bulb}

The SEM images of different sections of untreated and treated garlic bulbs are shown in Fig. 12. Mostly two types of sections (open and closed pore section) were seen in garlic. Ultrasound-treated and untreated garlic closed section has resemblance, whereas microwave-treated garlic has distorted pore structures and has a slight resemblance with the untreated garlic. Untreated garlic tissue had wellarranged pores and extracellular cuticles, whereas the microscopic image of microwave-treated garlic showed the disrupted cell walls, collapsed tissue, shrinkage in cell volume, and formation of the larger pore. The open-pore microstructure of both ultrasound- and microwave-treated garlic was profoundly influenced. The ultrasound-treated garlic has little uniform pore opening, whereas microwavetreated garlic has nonuniform pore structures, where some pores were wider and some were distorted. The change in the microscopic structure of garlic by microwave pretreatment might be due to the reorganization of extracellular cuticles, thermal expansion of cell walls, and collapse of several cellular layers due to the faster rate of heat and mass transfer at garlic dermal systems. During microwave treatment, water molecules could have directly absorbed microwave energy and the temperature dramatically increased; this might have increased the molecular mobility, which could have been the reason behind the shrink and distorted lost pore structure (Deng et al., 2015; Karunasena et al., 2014).

\section{The Practical Applicability of the US-MW Process}

On an industrial scale, the water or steam blanching process is carried out for 20-30 min, requiring a boiler or heater. The heating of the water to a pre-set temperature for tons of products also takes a lot of time due to a longer comeup time. Therefore, the development of 2 stage blanching process of ultrasonication followed by microwave heating for short time can eliminate the extra cost of boiler or heating unit, saving additional energy and installation cost. The preliminary study also showed that garlic drying time was reduced considerably after the US and MW pretreatment, along with high colour and aroma retention after drying.

\section{Conclusions}

Ultrasound pretreatment of garlic bulbs resulted in the reduction in POD activity by $22-85 \%$, PPO activity by 6-88\%, and Aspergillus niger count by 1.2 to 2.6 logs when US power density was varied from $38-72 \mathrm{Wg}^{-1}$. The highpower-short-time-microwave pretreatment ( 1 to $4 \mathrm{Wg}^{-1}$ and 40 to $180 \mathrm{~s}$ ) significantly reduced POD and PPO activity (12-87\%) and Aspergillus niger count by 0.4 to $2.3 \mathrm{logs}$ without affecting the original colour. Individually US or microwave treatment could not inactivate POD and PPO enzymes above $90 \%$. Therefore, a two-stage pretreatment process was developed where the garlic bulbs were treated with the optimized condition of ultrasound treatment (58.43 $\mathrm{WL}^{-1}$ ultrasound power density, initial bath temperature of $60{ }^{\circ} \mathrm{C}$ and 40 min ultrasonication duration) followed 
by microwave treatment, $3 \mathrm{Wg}^{-1}$ power density for $120 \mathrm{~s}$ duration which resulted in $90.37 \%$ POD and $92.38 \%$ PPO inactivation and 2.62 Aspergillus niger $\log$ reduction. The ultrasonication was found to enhance the efficiency of microwave heating in garlic bulbs. The SEM analysis revealed that the expansion of intercellular spaces due to ultrasonication treatment helped better penetration of microwaves and enhanced the microwave blanching-cum-black mould inactivation process.

Acknowledgements The authors are thankful to the Science \& Engineering Research Board (SERB), Government of India, for their financial support to this research work.

Data Availability All data generated or analysed during this study are included in the manuscript.

\section{Declarations}

Competing Interests The authors declare no competing interests.

\section{References}

Abdoli, B., Zare, D., Jafari, A., \& Chen, G. (2018). Evaluation of the air-borne ultrasound on fluidized bed drying of shelled corn: Effectiveness, grain quality, and energy consumption. Drying Technology, 36(14), 1749-1766. https://doi.org/10.1080/07373937.2018. 1423568

Alexandre, E. M., Santos-Pedro, D. M., Brandão, T. R., \& Silva, C. L. (2011). Study on thermosonication and ultraviolet radiation processes as an alternative to blanching for some fruits and vegetables. Food and Bioprocess Technology, 4(6), 1012-1019. https:// doi.org/10.1007/s11947-011-0540-8

AOAC. (1984). Official Methods of Analysis, 14th ed. Association of Official Analytical Chemists. Arlington, VA

Bayman, P., Baker, J. L., Doster, M. A., Michailides, T. J., \& Mahoney, N. E. (2002). Ochratoxin production by the Aspergillus ochraceus group and Aspergillus alliaceus. Applied and Environmental Microbiology, 68(5), 2326-2329. https://doi.org/10.1128/AEM. 68.5.2326-2329.2002

Benlloch-Tinoco, M., Varela, P., Salvador, A., \& Martínez-Navarrete, N. (2012). Effects of microwave heating on sensory characteristics of kiwifruit puree. Food and Bioprocess Technology, 5(8), 3021-3031. https://doi.org/10.1007/s11947-011-0652-1

Bozkir, H., Ergün, A. R., Tekgül, Y., \& Baysal, T. (2018). Ultrasound as pretreatment for drying garlic slices in microwave and convective dryer. Food Science and Biotechnology, 1-8. https://doi.org/ 10.1007/s10068-018-0483-1

Cao, X., Cai, C., Wang, Y., \& Zheng, X. (2018). The inactivation kinetics of polyphenol oxidase and peroxidase in bayberry juice during thermal and ultrasound treatments. Innovative Food Science \& Emerging Technologies, 45, 169-178. https://doi.org/10.1016/j. ifset.2017.09.018

Chamchong, M., \& Datta, A. (1999). Thawing of foods in a microwave oven: II. Effect of load geometry and dielectric properties. Journal of Microwave Power and Electromagnetic Energy, 34(1), 22-32. https://doi.org/10.1080/08327823.1999.11688385

Costa, M. G. M., Fonteles, T. V., de Jesus, A. L. T., Almeida, F. D. L., de Miranda, M. R. A., Fernandes, F. A. N., \& Rodrigues, S.
(2013). High-intensity ultrasound processing of pineapple juice. Food and Bioprocess Technology, 6(4), 997-1006. https://doi.org/ 10.1007/s11947-011-0746-9

Cruz, R. M., Vieira, M. C., \& Silva, C. L. (2006). Effect of heat and thermosonication treatments on peroxidase inactivation kinetics in watercress (Nasturtium officinale). Journal of Food Engineering, 72(1), 8-15. https://doi.org/10.1016/j.jfoodeng.2004.11.007

Dabir, M. P., \& Ananthanarayan, L. (2017). Effect of heat processing and ultrasonication treatment on custard apple peroxidase activity and vitamin C. International Journal of Food Engineering, 13(1).

de Barcelos Costa, H. C., Siguemoto, É. S., Cavalcante, T. A. B. B., de Oliveira Silva, D., Vieira, L. G. M., \& Gut, J. A. W. (2020). Effect of microwave-assisted processing on polyphenol oxidase and peroxidase inactivation kinetics of açai-berry (Euterpe oleracea) pulp. Food Chemistry, 128287.https://doi.org/10.1016/j. foodchem.2020.128287

Deng, Y., Padilla-Zakour, O., Zhao, Y., \& Tao, S. (2015). Influences of high hydrostatic pressure, microwave heating, and boiling on chemical compositions, antinutritional factors, fatty acids, in vitro protein digestibility, and microstructure of buckwheat. Food and Bioprocess Technology, 8(11), 2235-2245. https://doi. org/10.1007/s11947-015-1578-9

Devece, C., Rodríguez-López, J. N., Fenoll, L. G., Tudela, J., Catalá, J. M., \& de los Reyes, E., \& García-Cánovas, F. (1999). Enzyme inactivation analysis for industrial blanching applications: Comparison of microwave, conventional, and combination heat treatments on mushroom polyphenoloxidase activity. Journal of Agricultural and Food Chemistry, 47(11), 4506-4511. https://doi.org/10.1021/jf981398+

Devi, A. F., Au, X. N., Weerakkody, R., Sanguansri, P., Swiergon, P., Singh, T., Ng, S., \& Gamage, T. V. (2021). Microwave pasteurised pear snack: quality and microbiological stability. Food and Bioprocess Technology, 1-16. https://doi.org/10.1007/ s11947-021-02642-x

Durek, J., Schlüter, O., Roscher, A., Durek, P., \& Fröhling, A. (2018). Inhibition or stimulation of ochratoxin a synthesis on inoculated barley triggered by diffuse coplanar surface barrier discharge plasma. Frontiers in Microbiology, 9, 2782. https://doi.org/10. 3389/fmicb.2018.02782

Etzbach, L., Pfeiffer, A., Schieber, A., \& Weber, F. (2019). Effects of thermal pasteurization and ultrasound treatment on the peroxidase activity, carotenoid composition, and physicochemical properties of goldenberry (Physalis peruviana L.) puree. LWT, 100, 69-74. https://doi.org/10.1016/j.lwt.2018.10.032

Fante, L., \& Noreña, C. P. Z. (2012). Enzyme inactivation kinetics and colour changes in Garlic (Allium sativum L.) blanched under different conditions. Journal of Food Engineering, 108(3), 436-443. https://doi.org/10.1016/j.jfoodeng.2011.08.024

Fernandes, F. A., Linhares, F. E., Jr., \& Rodrigues, S. (2008). Ultrasound as pre-treatment for drying of pineapple. Ultrasonics Sonochemistry, 15(6), 1049-1054. https://doi.org/10.1016/j.ultsonch. 2008.03.009

Gamboa-Santos, J., Montilla, A., Soria, A. C., \& Villamiel, M. (2012). Effects of conventional and ultrasound blanching on enzyme inactivation and carbohydrate content of carrots. European Food Research and Technology, 234(6), 1071-1079. https://doi.org/10. 1007/s00217-012-1726-7

González, M. G. M., Romero, S. M., Arjona, M., Larumbe, A. G., \& Vaamonde, G. (2017). Microbiological quality of Argentinian paprika. Revista Argentina De Microbiologia, 49(4), 339-346. https://doi.org/10.1016/j.ram.2017.02.006

Han, Z., Cai, M.-J., Cheng, J.-H., \& Sun, D.-W. (2018). Effects of electric fields and electromagnetic wave on food protein structure and functionality: A review. Trends in Food Science \& Technology, 75, 1-9. https://doi.org/10.1016/j.tifs.2018.02.017 
Huang, Y., Sheng, J., Yang, F., \& Hu, Q. (2007). Effect of enzyme inactivation by microwave and oven heating on preservation quality of green tea. Journal of Food Engineering, 78(2), 687-692. https:// doi.org/10.1016/j.jfoodeng.2005.11.007

Jahanbakhshi, A., Kaveh, M., Taghinezhad, E., \& Rasooli Sharabiani, V. (2020). Assessment of kinetics, effective moisture diffusivity, specific energy consumption, shrinkage, and color in the pistachio kernel drying process in microwave drying with ultrasonic pretreatment. Journal of Food Processing and Preservation, e14449. https://doi.org/10.1111/jfpp.14449

Jang, J.-H., \& Moon, K.-D. (2011). Inhibition of polyphenol oxidase and peroxidase activities on fresh-cut apple by simultaneous treatment of ultrasound and ascorbic acid. Food Chemistry, 124(2), 444-449. https://doi.org/10.1016/j.foodchem.2010.06.052

Kar, S., Mujumdar, A. S., \& Sutar, P. P. (2018). Aspergillus niger inactivation in microwave rotary drum drying of whole garlic bulbs and effect on quality of dried garlic powder. Drying Technology, 1-13.https://doi.org/10.1080/07373937.2018.1517777

Karunasena, H., Hesami, P., Senadeera, W., Gu, Y., Brown, R. J., \& Oloyede, A. (2014). Scanning electron microscopic study of microstructure of gala apples during hot air drying. Drying Technology, 32(4), 455-468. https://doi.org/10.1080/07373937.2013. 837479

Klug, T. V., Collado, E., Martínez-Sánchez, A., Gómez, P. A., Aguayo, E., Otón, M., Artés, F., \& Artés-Hernandez, F. (2018). Innovative quality improvement by continuous microwave processing of a faba beans pesto sauce. Food and Bioprocess Technology, 11(3), 561-571. https://doi.org/10.1007/s11947-017-2024-y

Liu, F., Niu, L., Li, D., Liu, C., \& Jin, B. (2013). Kinetic characterization and thermal inactivation of peroxidase in aqueous extracts from sweet corn and waxy corn. Food and Bioprocess Technology, 6(10), 2800-2807. https://doi.org/10.1007/s11947-012-0996-1

Marszałek, K., Mitek, M., \& Skąpska, S. (2015). Effect of continuous flow microwave and conventional heating on the bioactive compounds, colour, enzymes activity, microbial and sensory quality of strawberry purée. Food and Bioprocess Technology, 8(9), 18641876. https://doi.org/10.1007/s11947-015-1543-7

Matsui, K. N., Gut, J. A. W., De Oliveira, P. V., \& Tadini, C. C. (2008). Inactivation kinetics of polyphenol oxidase and peroxidase in green coconut water by microwave processing. Journal of Food Engineering, 88(2), 169-176. https://doi.org/10.1016/j.jfoodeng. 2008.02 .003

Mothibe, K. J., Zhang, M., Mujumdar, A. S., Wang, Y. C., \& Cheng, X. (2014). Effects of ultrasound and microwave pretreatments of apple before spouted bed drying on rate of dehydration and physical properties. Drying Technology, 32(15), 1848-1856. https://doi. org/10.1080/07373937.2014.952381

Nalawade, S. A., Sinha, A., \& Hebbar, H. U. (2018). Infrared based dry blanching and hybrid drying of bitter gourd slices: Process efficiency evaluation. Journal of Food Process Engineering, 41(4), e12672. https://doi.org/10.1111/jfpe.12672

Pankaj, S., Shi, H., \& Keener, K. M. (2018). A review of novel physical and chemical decontamination technologies for aflatoxin in food. Trends in Food Science \& Technology, 71, 73-83. https://doi.org/ 10.1016/j.tifs.2017.11.007

Park, J. J., Olawuyi, I. F., \& Lee, W. Y. (2021). Influence of Thermosonication and Ascorbic Acid Treatment on Microbial Inactivation and Shelf-Life Extension of Soft Persimmon (Diospyros kaki T.) Juice. Food and Bioprocess Technology, 14(3), 429-440. https:// doi.org/10.1007/s11947-021-02580-8

Riba, A., Mokrane, S., Mathieu, F., Lebrihi, A., \& Sabaou, N. (2008). Mycoflora and ochratoxin A producing strains of Aspergillus in Algerian wheat. International Journal of Food Microbiology, 122(1-2), 85-92. https://doi.org/10.1016/j.ijfoodmicro.2007.11. 057
Rodrigues, S., \& Fernandes, F. A. (2007). Use of ultrasound as pretreatment for dehydration of melons. Drying Technology, 25(10), 1791-1796. https://doi.org/10.1080/07373930701595409

Rojas, M. L., Trevilin, J. H., dos Santos Funcia, E., Gut, J. A. W., \& Augusto, P. E. D. (2017). Using ultrasound technology for the inactivation and thermal sensitization of peroxidase in green coconut water. Ultrasonics Sonochemistry, 36, 173-181. https://doi. org/10.1016/j.ultsonch.2016.11.028

Rokhina, E. V., Lens, P., \& Virkutyte, J. (2009). Low-frequency ultrasound in biotechnology: State of the art. Trends in Biotechnology, 27(5), 298-306. https://doi.org/10.1016/j.tibtech.2009.02.001

Saeeduddin, M., Abid, M., Jabbar, S., Wu, T., Hashim, M. M., Awad, F. N., Hu, B., Lei, S., \& Zeng, X. (2015). Quality assessment of pear juice under ultrasound and commercial pasteurization processing conditions. LWT-Food Science and Technology, 64(1), 452-458. https://doi.org/10.1016/j.lwt.2015.05.005

Salazar-González, C., San Martín-González, M. F., López-Malo, A., \& Sosa-Morales, M. E. (2012). Recent studies related to microwave processing of fluid foods. Food and Bioprocess Technology, 5(1), 31-46. https://doi.org/10.1007/s11947-011-0639-y

Shirkole, S., Jayabalan, R., \& Sutar, P. (2020). Dry sterilization of paprika (Capsicum annuum L.) by short time intensive microwave-infrared radiation: Establishment of process using glass transition, sorption, and quality degradation kinetic parameters. Innovative Food Science \& Emerging Technologies, 102345. https://doi.org/10.1016/j.ifset.2020.102345

Silva, L. C., Almeida, P. S., Rodrigues, S., \& Fernandes, F. A. (2015). Inactivation of polyphenoloxidase and peroxidase in apple cubes and in apple juice subjected to high intensity power ultrasound processing. Journal of Food Processing and Preservation, 39(6), 2081-2087. https://doi.org/10.1111/jfpp.12451

Tiwari, B., Muthukumarappan, K., \& O'donnell, C., \& Cullen, P. (2008). Effects of sonication on the kinetics of orange juice quality parameters. Journal of Agricultural and Food Chemistry, 56(7), 2423-2428. https://doi.org/10.1021/jf073503y

Torki-Harchegani, M., Ghanbarian, D., Pirbalouti, A. G., \& Sadeghi, M. (2016). Dehydration behaviour, mathematical modelling, energy efficiency and essential oil yield of peppermint leaves undergoing microwave and hot air treatments. Renewable and Sustainable Energy Reviews, 58, 407-418. https://doi.org/10. 1016/j.rser.2015.12.078

Trovato, L., Calvo, M., Migliorisi, G., Astuto, M., Oliveri, F., \& Oliveri, S. (2021). Fatal VAP-related pulmonary aspergillosis by Aspergillus niger in a positive COVID-19 patient. Respiratory Medicine Case Reports, 32, 101367. https://doi.org/10.1016/j.rmcr.2021. 101367

Wang, J., Cao, Y., Sun, B., Wang, C., \& Mo, Y. (2011). Effect of ultrasound on the activity of alliinase from fresh garlic. Ultrasonics Sonochemistry, 18(2), 534-540. https://doi.org/10.1016/j.ultsonch. 2010.09.008

Yao, Y., Wei, X., Pang, H., Wang, K., Liu, Q., Fu, H., Chen, X., \& Wang, Y. (2020). Effects of radio-frequency energy on peroxidase inactivation and physiochemical properties of stem lettuce and the underlying cell-morphology mechanism. Food Chemistry, 126753. https://doi.org/10.1016/j.foodchem.2020.126753

Yildiz, G., \& Izli, G. (2019). The effect of ultrasound pretreatment on quality attributes of freeze-dried quince slices: Physical properties and bioactive compounds. Journal of Food Process Engineering, 42(5), e13223. https://doi.org/10.1111/jfpe.13223

Yoruk, R., \& Marshall, M. R. (2003). Physicochemical properties and function of plant polyphenol oxidase: a review 1. Journal of Food Biochemistry, 27(5), 361-422. https://doi.org/10.1111/j. 1745-4514.2003.tb00289.x

Yu, J., Engeseth, N. J., \& Feng, H. (2016). High intensity ultrasound as an abiotic elicitor-effects on antioxidant capacity and overall 
quality of romaine lettuce. Food and Bioprocess Technology, 9(2), 262-273. https://doi.org/10.1007/s11947-015-1616-7

Zhang, Z., Niu, L., Li, D., Liu, C., Ma, R., Song, J., \& Zhao, J. (2017). Low intensity ultrasound as a pretreatment to drying of daylilies: Impact on enzyme inactivation, color changes and nutrition quality parameters. Ultrasonics Sonochemistry, 36, 50-58. https://doi. org/10.1016/j.ultsonch.2016.11.007

Zhang, X.-T., Zhang, M., Devahastin, S., \& Guo, Z. (2019). Effect of combined ultrasonication and modified atmosphere packaging on storage quality of pakchoi (Brassica chinensis L.). Food and Bioprocess Technology, 12(9), 1573-1583.
Zheng, H., \& Lu, H. (2011). Effect of microwave pretreatment on the kinetics of ascorbic acid degradation and peroxidase inactivation in different parts of green asparagus (Asparagus officinalis L.) during water blanching. Food Chemistry, 128(4), 1087-1093. https://doi.org/10.1016/j.foodchem.2011.03.130

Publisher's Note Springer Nature remains neutral with regard to jurisdictional claims in published maps and institutional affiliations. 